Portland State University

PDXScholar

Spring 6-19-2017

\title{
Shouts of the Khori-Challwa: Andean Mythological and Cosmological Reconsiderations of the American Identity in Gamaliel Churata's El pez de oro
}

Stephen Delaney McNabb

Portland State University

Follow this and additional works at: https://pdxscholar.library.pdx.edu/open_access_etds

Part of the Latin American Studies Commons, and the Spanish Literature Commons Let us know how access to this document benefits you.

\section{Recommended Citation}

McNabb, Stephen Delaney, "Shouts of the Khori-Challwa: Andean Mythological and Cosmological Reconsiderations of the American Identity in Gamaliel Churata's El pez de oro" (2017). Dissertations and Theses. Paper 4010.

https://doi.org/10.15760/etd.5894

This Thesis is brought to you for free and open access. It has been accepted for inclusion in Dissertations and Theses by an authorized administrator of PDXScholar. Please contact us if we can make this document more accessible: pdxscholar@pdx.edu. 
Shouts of the Khori-Challwa:

Andean Mythological and Cosmological Reconsiderations of the American Identity in Gamaliel Churata's El pez de oro

by

Stephen Delaney McNabb

A thesis submitted in partial fulfillment of the requirements for the degree of

\author{
Master of Arts \\ in \\ Spanish \\ Thesis Committee: \\ Enrique Cortez, Chair \\ Craig Epplin \\ Cynthia Sloan \\ Ines Warnock \\ Portland State University \\ 2017
}


C 2017 Stephen Delaney McNabb 


\begin{abstract}
This thesis explores the possible creation of a new categorization of American Literature as presented in the Andean novel El pez de oro: Retablos del Laykhakuy (1957) by Gamaliel Churata. In El pez de oro, Gamaliel Churata presents a strategy for the recuperation of native Andean cultural agency that enables the Andean subject to reclaim traces of their ancestral past under more verisimilar and verifiable terms. Churata argues that through a recuperation of native language and its infusion into the body of the major colonial language, Spanish, the Andean subject is equipped with a new culture producing tool that enables the recuperation of language, agency, history, and, ultimately, representation and inclusion within cultural and political institutional frameworks. By introducing his own function of bilingualism, vernacular language, and mythological infusions into the body of colonial letters, Gamaliel Churata is able to destabilize and disrupt colonial historical and textual authority to the point where the invented concept of America and the colonial product of American identity can be re-examined. Through this examination emerges a new option for the categorization of American identity as an aesthetic construct. Within this new categorization of aesthetic American identity, the Andean subject can begin his own process of self-identification through his native language toward the production of a future Andean American subject.
\end{abstract}




\section{Acknowledgements}

I would first like to thank my adviser Dr. Enrique Cortez for introducing me to the world of Gamaliel Churata and El pez de oro, which will continue to be a guiding light throughout the entirety of my academic and professional career. I would like to thank my other committee members, Dr. Craig Epplin, Dr. Cynthia Sloan, and M.A. Ines Warnock for their support, encouragement, and constructive criticism toward the completion of this thesis. My mother deserves special recognition for her pushing toward my academic development; I would not have been able to do it without you. Finally, I would like to thank my partner, Arely Vega Garcia, for being an infinite source of inspiration and motivation. 


\section{Table of Contents}

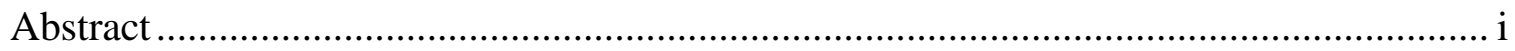

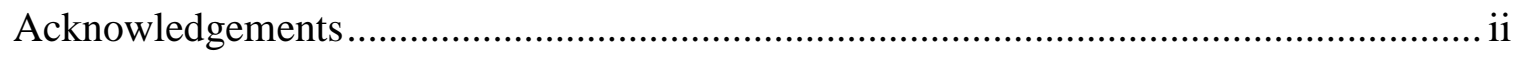

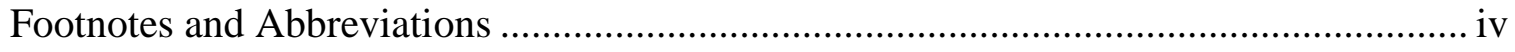

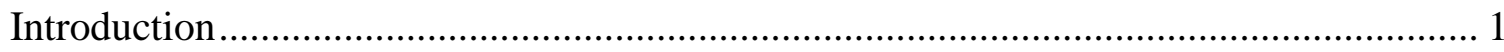

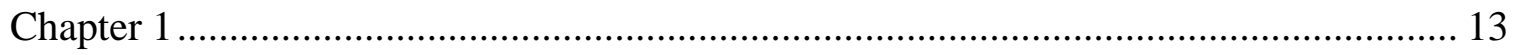

The Place of Gamaliel Churata and El pez de oro in the World of Andean Letters......... 13

Homilía del Khori-Challwa and the Possibility of American Literature ........................ 36

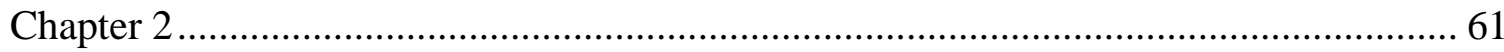

Quechumara and the Role of Minor Literature in "Morir de América" ......................... 61

The Hurin Dilemma: Andean Cosmology and the Discovery of America in

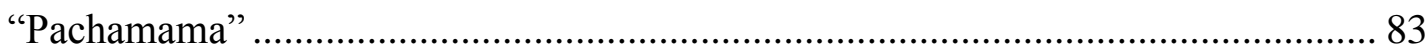

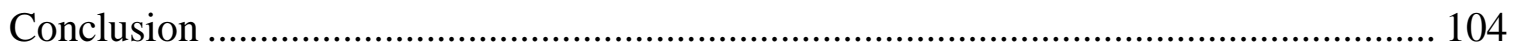

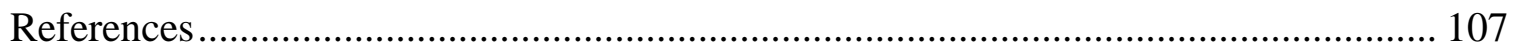




\section{Footnotes and Abbreviations}

All footnotes marked (Guión) indicate that these Quechua, Aymara, or Quechumara words, neologisms, vernacular, and hybrid words are transcribed directly from the section Guión lexigráfico (pp. 975-1022) in the 2012 Cátedra edition of El pez de oro by Helena Usandizaga. This extratextual section is crucial when working through Gamaliel Churata's language who often refers to archaic or baroque language, not to mention words devised from within his own linguistic hybridizations.

Kh. Quechua. Many hold older more archaic or phonetic spellings.

Ay. Aymara.

Kh. -Ay. $\quad$ A shared word between the Quechua and Aymara cultures.

Dim. Diminutive form.

Plb. A "plebeyo" or vernacular word common in popular Andean speech.

Hib. Hybrid word of varied origins.

Neo. Neologism of Churata's own invention. 


\section{Introduction}

The invention of America at the point of first contact between the European colonizers and the inhabitants of the New World takes shape in North American Literature as the preordained discovery of a world filled with inexplicable riches and new possibilities of

freedom for European subjects escaping imperial rule. What started as the colonization of the Caribbean, Central, and South America turned into an unquenchable need to go west and discover new land that offers new origins, ultimately culminating in the development of the modern North American society and the United States. The American mythos is built upon the representation of a subject who journeys west into the unknown and becomes a symbol for freedom, individuality, and prosperity. American Literature, contained to the North American context, reflects the spirit of discovery where the New World and the West present endless opportunities for those willing to charter out and stake their own claim in the land.

What the North American appropriation of the title "American Literature" discounts is the fact that the invention of America and the foundations of American Literature were engendered on colonialism, enslavement, and cultural erasure. Yet this perspective is forgotten when considering the master narrative of American Literature as one that favors modernity and dominance, rather than the perspective of dominated people. More, by applying the categorization of American Literature solely to literature emerging from the United States, the intersectionality of the idea of America that has been developing over five centuries from North to South America is denied and only the European cultural impact is taken into account when constructing an American identity. What should be an identity formed through an intercultural dialogue toward the creation 
of a heterogeneous culture constructed through a "center periphery perspective" reverts into the myth of modernity (Dussel 341). ${ }^{1}$ From this divided nature of North-South cultural and historical dialogues, American Literature can be rationally categorized as both a literature of freedom and of enslavement, prosperity and impoverishment. This fracture between what constitutes American Literature and, by proxy, American identity constitutes the basic question that drives Gamaliel Churata's vision for the constitution of a renewed American identity that is truly heterogeneous.

Despite their different connotations, North American and Latin American

Literature both focus on the investigation of how national identity can be constructed by tracing their mythological origins, questioning their past, and allowing new beginnings. While North America readers regard their American Literature as a symbol for new beginnings and origins, the Latin American reader engages their literature as a means of reviving traces of their lost past in hopes of engendering a new beginning. The introduction to Coloniality at Large presents this dichotomy clearly when highlighting how the modern definition of American Literature continuously engenders the creation of a new world constructed on top another. In this way, American Literature engages in a process towards its own destruction, "it expresses a vision of another New World, for which yet another colonial beginning is imagined" (1). What this citation permits is a consideration of American Literature, not as a body of work contained to the American

\footnotetext{
${ }^{1}$ Enrique Dussel's philosophy of liberation is focused on the idea that the centrality of world history is Eurocentric and reduces all non-European cultures to a position of exclusion within this history. Through philosophy of liberation, these excluded subjects attempt to establish a new center-periphery perspective that pushes back against European discourse toward the construction of a new North-South dialogue that allows for the reconstitution of oppressed races, cultures, histories, languages, etc... (Dussel 342). See Dussel's Philosophy of Liberation for a deeper analysis on this topic.
} 
colonies and the United States, rather as a cultural practice engaged with an endless process of engendering new worlds whose origins are wholly imagined and whose histories are denied. Through this interpretation of American Literature as a nationless identity which allows multiple origins, there is a space for the recuperation of erased culture, a decentering of colonial authority, and the reconstitution of cultural agency and production through native languages.

The inclusion of the conflict regarding the homogenizing effect of American identity, and its multiple interpretations regarding disperse racial and geographic groups, is important to this thesis in terms of allowing for an understanding of the dormant cultural consciousness which Gamaliel Churata sought to resurrect through his writing. As a thesis written in English, this thesis aims to appeal toward North American, as well as global, readers as a means of encouraging future research and scholarship regarding $E l$ pez de oro, the entirety of Churata's literary works, and other projects engaged with exploring colonial classifications of power and identity.

This thesis is concerned with the exploration of the invention of America and the recuperation of Andean cultural components (language, history, and literature) within Gamaliel Churata's El pez de oro: Retablos del Laykhakuy (1957) toward the possibility of a new American subject. This underappreciated Andean novel existed on the periphery of Peruvian, as well as Latin American Literature, before its slow resurrection beginning in the late 1970's leading up to an academic boom in 2012 with the publication of Cátedra's critical edition, edited by Helena Usandizaga. The publication of the Cátedra edition of El pez de oro opened Gamaliel Churata into a global readership, as prior to the new edition it had become a daunting task in itself to simply find a copy of the previous 
two editions. Within the Cátedra edition, Usandizaga offers a wide range of critical essays regarding El pez de oro, the life of Churata, as well as a lexicographic guide to help the reader work through Churata's infusions of indigenous languages and use of neologisms. The publication of this latest edition also marks a tremendous leap forward in terms of allowing Churata a global readership which he previously lacked. I believe $E l$ pez de oro's inclusion within the Cátedra catalog, while still lacking a wide audience, signals a significant step toward its inclusion within the Peruvian, Andean, and Latin American literary canons. Besides the Cátedra edition, the publication of other important works regarding El pez de oro between 2012-2015 allow for more contextualized readings of such a difficult work that will facilitate future scholarship. ${ }^{2}$ The labors of these literary efforts culminated in the first North American conference dedicated towards a study of Gamaliel Churata that took place at the University of Pittsburgh in November 2016.

The conference at the University of Pittsburgh revealed the extent of Churatian studies which are taking place on a global scale, Riccardo Badini in Italy, Marco Bosshard in Germany, Helena Usandizaga in Spain, Maya Aguiluz Ibargüen in Mexico, not to mention the scale of Andean intellectuals developing Churatian studies within Latin America and the Andean altiplano. Throughout the conference, these speakers discussed the continued relevance of Churata in a globalized world, his forethought on ideas of transmodernity in a decolonial landscape, challenges presented within his

${ }^{2}$ Churata y la vanguardia andina by Marco Bosshard, Quechumara: Proyecto estético-político de Gamaliel Churata by Mauro Mamami Macedo, Encrucijadas estético-políticas en el espacio andino edited by Maya Aguiluz Ibargüen, and La vanguardia plebeya del Titikaka by Elizabeth Monasterios are four seminal Churatian texts published between 2012-2015. 
writing, and possible solutions for introducing Churata as a prime example of the conflicted and contradictory stature of Latin American identity. As a graduate student still finding my own way through Churata's disjointed structure and aesthetic language, I was surprised at how the readers were able to approach an analysis to Churata and $E l \mathrm{pez}$ de oro by fragmenting a reading of the book in order to uncover deep-lying structures, themes, and the role of Churata's novel, which may be more appropriately defined as a decolonial aesthetic project.

I use the term "decolonial" over the more common "postcolonial" theory as I believe they hold slight variations in their definitions and contexts where Churata can be better situated within decolonial theory. When considering the structure of postcolonial theory as presented by Edward Said and Franz Fanon, little attention has been paid to the role of the North-South dialogue or the role of America within the development of postcolonial contexts. Said, in Culture and Imperialism, presents postcolonial contexts as contemporary ones where developments pertaining to the period of first contact and colonization are not taken into consideration. More than a concentration on historical periods, Said and Fanon were both focused more on the developments of imperialism in Asia and Africa than in the Americas. Rolena Adorno in her article "Reconsidering Colonial Discourse for Sixteenth- and Seventeenth-Century Spanish America," notes how the common theories and discourses fail to consider Latin America:

The critical components and theories of colonialism, as inventions of the study of the colonial experiences in the nineteenth and twentieth centuries, are inappropriate for shaping ideas about the experience of Spanish America from the sixteenth through the mid-eighteenth centuries. (141)

While this thesis is concerned with the period of early twentieth century indigenism in the 
Andes, the conditions of colonial experience remain very applicable and are needed to help situate the more modern period of colonial discourse. ${ }^{3}$

Beyond a historical or geopolitical difference and into more substantive claims of overlap and difference between decolonial and postcolonial theory, both theories share a theoretical starting point of addressing colonialism as the "transatlantic expansion of colonial domination and the perpetuation of its effects into contemporary times" (Coloniality at Large 2). While sharing a cultural and political crossroad for examining Latin American reality, different theorists help define their distinct characteristics. Postcolonial theorist Peter Hulme in his essay "Postcolonial Theory and the Representation of Culture in the Americas" defines postcolonial theory as:

a way of describing a body of work which attempts to break with the colonialist assumptions that have marked many of the projects of political and cultural criticism launched from Europe...while learning from and frequently refiguring those theoretical projects in the interests of analysis of and resistance to the networks of imperial power which continue to control most of the world. (388)

Hulme goes on to make it clear that the use of the term "postcolonial" is one still in debate and that imperialism, postcolonialism, decolonialism, modernity, and colonialism are all terms whose definitions still escape definitive dates and foundations between different academic circles (390). Hulme prefers the term postcolonial to refer to ideologies analyzing the networks of power emerging within systems of coloniality. Despite these concerns regarding postcolonial theory being addressed within El pez de oro, Gamaliel Churata aligns more closely with decolonial theory if we accept the definition put forth by Walter Mignolo in "Geopolitics of Sensing and Knowing," a

\footnotetext{
${ }^{3}$ Fernando Coronil's article "Elephants in the Americas? Latin American Postcolonial Studies and Global Decolonization" lends a great argument for how the Latin American context lends itself much closer to decolonial than postcolonial theories.
} 
prominent figure within decolonial theory. Mignolo summarizes:

The main goal...was to find common ground and vision for the future that was neither capitalism nor communism. That was decolonization...from now to the future, it will be decoloniality all the way down - not as a new universal that presents itself as the right one that supersedes all the previous and existing ones, but as an option. (273, italics mine)

For Mignolo, what distinguishes decolonial theory from postcolonial theory is its possibility as applicable to issues of modernity whose resolutions exist outside common binary frameworks. As I will argue throughout this thesis, Gamaliel Churata envisioned his new American subject and literature as a future project that wishes to introduce continuous variation and processes of heterogeneity within modern cultural production. More, while Churata investigates these practices through language and narrative variation, they can be enacted within any social or cultural component that engages with steps toward decolonialism. Nelson Maldonado-Torres explains this diverse positioning of decoloniality, "decolonial...does not refer to a single theoretical school, but rather points to a family of diverse positions that share a view of coloniality as a fundamental problem in the modern age, and of decolonization or decoloniality as a necessary task that remains unfinished...decolonization will remain unfinished for some time" (2-3). Much like decoloniality, Churata's aesthetic project will remain unfinished for some time as it requires an inter-generational experimentation and adaption of culture and vernacular language.

Within decolonial theory, gender, sexuality, and politics carry just as much colonial baggage as ethnicity and language. This goal of finding common ground between distinct cultures towards the creation of a new subject, language, and literature plays a vital role within Churata's vision for a new collective Andean spirit where his 
aesthetic project remains a continuous process in its aspiration toward the constitution of a new American Literature not defined by capitalistic or communistic resolutions. El pez de oro is not a representation of the Andean reality, it is an expression of the Andean worldview and should be read as a decolonial aesthetic project rather than a postcolonial dilemma.

Mignolo lends a second focus of decolonial theory that distinguishes itself from postcoloniality that remains important to this study. The role of border thinking as "the epistemic singularity of any decolonial project” (“Geopolitics of Sensing” 274). Border thinking, as a branch of the decolonial option, is a rejection of colonial discourse which places racial or cultural groups in the position of the other as a means of forcing them to assimilate and accept their perceived inferiority, "to assimilate means that you accept your inferiority and resign yourself to play the game that is not yours but that has been imposed upon you" (275). Border thinking allows dominated subjects to invert colonial identity and to recast it under their own terms which come about through "changing the terms of the conversation and not only its content" (ibid). This changing the terms of the conversation and refusing to play the game of cultural assimilation drives Churata's writing in his attempt to create a new space for Andean cultural production enabled by their own agents. Decoloniality allows Churata to decouple European institutions from the Andean subject, expose institutionalized identities as fiction, and to create the possibility of a new Andean world.

More than a theory which allows for a reconsideration of constructed colonial power where indigenous groups can begin to orient their own way of thinking, decolonial theory seek to construct the idea of a "pluriuniversal world order" (Darker Side xv) 
where diverse worldviews can be included within a single locality. Within this mix of worldviews towards the deconstruction of imposed colonial hierarchies, the minority group must seek modes of elevating their sociopolitical inclusion in order to be included in the distribution of control over knowledge, economy, and freedom.

Towards the goal of liberating autonomous Andean expression, Churata's writing aligns itself with the literary practice of minor literature. Engaged with stripping away layers of colonial domination and allowing the reconstitution of colonial power, minor literature is a very applicable concept to El pez de oro where the principal narrator searches for a language to lend expression to the world he was born into, yet now feels isolated from. The role of minor literature is to call attention to the decolonial possibilities that language allows when written from within a minority group. This minor language within a major one constructs the foundation for the reconstitution of cultural agency in a colonial context. The means of situating the expression of an oppressed racial or cultural majority group within the major language and colonial society forms the base of a minor literature.

The first chapter will lend a sociopolitical context to the period of production regarding El pez de oro, specifically the conflict of colonialism and modernity in early twentieth century Peru that led to the indigenism movement engaged with the restitution of Andean cultural and intellectual autonomy. Through a concentration on the structure, language, style, and classification of El pez de oro, the reader of this thesis will be better situated to approaching the text's complexities which have historically kept it removed from the Latin American canon. Moving beyond the extra-textual contexts, the second half of the first chapter will explore the possibility of this new American language within 
the retablo "Homilía a Khori-Challwa" of El pez de oro. Within "Homilía" Churata begins to excavate the history of the Peruvian literary tradition as a cultural practice of resistance. Beginning at a critical analysis of the writing of the cronistas before engaging in his own form of cultural hybridity, Churata concludes the opening retablo by allowing an interpretation of his own hybrid strategy for the constitution of a new American language, or aesthetic project, - Quechumara. This section will conclude by setting the stage for the interpretation of Quechumara as the foundation for the categorization of $E l$ pez de oro as a minor literature. Such a categorization enables a renewed sense of cultural agency within the new Andean American subject where Andeans can reclaim their origins while not regressing into utopic or other regressive forms of cultural revival.

The second chapter will critically engage the function of Churata's aesthetic project, Quechumara, in allowing the reconstitution of Andean cultural agency, and its possibilities for forging a new Andean future. The first half of this chapter will engage a definition of Churata's aesthetic language project, Quechumara, as the foundation for the classification of El pez de oro as a minor literature. Through an analysis of the performative retablo "Morir de América," the function of Quechumara as a decolonial minor language can be constructed as one that enables renewed possibilities of Andean cultural survival in a modernized colonial context.

After establishing the vital function of Quechumara, the latter half of the second chapter will investigate how Quechumara and Churata's idea of America as a fictionalized historical identity allow for a reconstitution of Andean historical memory by destabilizing European textual and historical authority. Within the retablo "Pachamama" Churata engages the cultural difference between ideas of cosmology, mythological 
origins, and narrative structures between the Andean and European worldviews to highlight how the invention of America appropriated Andean ideas of history, time, and space and converted them to fit European ideals. "Pachamama" puts Churata's critical theory into motion through a metafictional rewriting of Christopher Columbus's arrival into the Americas. Through a rewriting of the discovery and invention of America that favors Andean aesthetics and enables Andean cultural agency within a new vision of the American identity, this chapter enables a number of future revisions to Andean modernity with the Andean subject as its main subject and actor. Concerned with conflicts of history, narrative, and time and space concerning the European and Andean worldviews, Churata's metafictional approach to the invention of America is vital in demonstrating the distance between the European and Andean worldviews where American history can be seen not as holding fixed meaning in the past, but rather as a contemporary reflection of imposed colonial identity.

Despite the breadth of any comprehensive critical investigation, El pez de oro remains a challenging and daunting novel in its aim to decolonize Andean cultural production and representation through a new Andean aesthetic expressed through a hybrid language that relies heavily on the pre-colonial Andean oral tradition and decolonial strategies for intellectual and cultural autonomy. Besides its characterization as an impossible text, "El pez de oro seguía como un libro casi imposible de leer" (Usandizaga 13), Churata's novel does not have to be presented in such a daunting manner and can be made accessible to all audiences when situated within its historical, cultural, ideological, and artistic context.

This thesis is only one of many possible readings regarding these individual 
retablos and Churata's vision for the constitution of a new American Literature. While Churata's voice allows for a wide range of readings dealing with a wide range of cultural components and political contexts, an entrance into Churata's Andean world is best situated within the context of the development of modernity and indigenism in the first half of the twentieth century. 


\section{Chapter 1 \\ The Place of Gamaliel Churata and El pez de oro in the World of Andean Letters}

El pez de oro: Retablos del Laykhakuy (1957) by Gamaliel Churata is an Andean novel that has seemingly defied classification and existed on the periphery of the Latin American literary canon over the past five decades. Yet Gamaliel Churata's masterwork, three-decades in the making, is now being hailed of one of the most important twentiethcentury texts to emerge from the Andean altiplano, if not from within Latin America itself. In 1989, Peruvian literary scholar Antonio Cornejo Polar called Churata's novel one of the greatest unstudied achievements in Peruvian literature. In Churata's obituary in the November of 1969 edition of Correo, Ántero Peralta Vásquez described El pez de oro as a "libro original, singularísimo. Es, a la vez, relato, poesía, historia, sociología, literatura, etnología, ciencia, y filosofía, y no es nada de eso en sentido estricto.”

This sentiment by Peralta Vásquez helps the reader to deduce that a categorization of Gamaliel Churata within a genre, let alone a canon, remains a difficult, if not impossible, task. Churata's own publisher, Fernando Díez de Molina questioned where the legacy of the Andean author would align in the future, “¿pero qué es El pez de oro? Difícil, si no es imposible clasificarlo. Novela, no. Tampoco tratado filosófico. Ni ensayo sociológico. Para prosa lírica, sobra substancia. Para interpretación histórica, faltan sistema y método" (395). This lack of clear method, as it attempted to create a new method and practice of language, left El pez de oro a short-lived success that has been finding new avenues of investigation over the past three decades. The reasons for Churata's disappearance and contemporary resurgence are manifold and relate to a mixing of genres, languages, voices, and narrative forms where the role of Andean 
mythology becomes the driving narrative force and the Andean aesthetic as its principal voice.

Composed of eleven novella-length retablos, El pez de oro combines poetry, fiction, history, ethnography, nonfiction essays, distinct vernacular languages, aesthetic prose, and performative textuality. Each of these collide to share a space of lettered cultural production where Andean tradition and European modernity come together to form a new unconventional novel whose goals ultimately lie in the future. The role of this aesthetic project as a future one refers to the role of the decolonial option in forging a more heterogeneous and polycentric worldview where no single ideology or civilization is permitted dominance over the other. Yet the fruits of this labor cannot be brought about within a single generation. Rather, Churata envisioned the creation of an ongoing process of continuous change and variation within the definition of American identity.

A focus on the role of typical fictional narrative structures would do well to remember that Andean mythological figures serve as the novel's main protagonists and fulfill a mainly symbolic function. Helena Usandizaga notes in her introduction to the Cátedra edition the vital role that Andean myth places within the novel, "los mitos andinos se muestran como huellas de historias de tipo muy general" (44). Given the unconventional narrative structure and the symbolic function of the narrator and characters, any individual summary of El pez de oro is bound to favor one theme or subjective focus over another. A conventional Western summary would likely prioritize the role of the central protagonist, Khori-Challwa, and issues concerning his individuality set against a backdrop of political or social context. This character driven Western summary would sound something like the following paragraph. 
Born in the land of his forefathers, Khori-Challwa is caught between an allegiance to the language, traditions, and land that have sustained his family for generations against the pull of the world outside the shores of Lake Titicaca. As the cultural and economic consequences of modernity threaten everything he has known, Khori-Challwa must confront the skeletons of the living dead, threats of impending violence, and a monster endlessly in his pursuit. Coming face to face with the monster threatening his past, present, and future, Khori-Challwa must find his place within both worlds in his battle for survival.

While my westernized summary prioritizes the driving central narrative, this narrative is only one of many working parts within a novel that can also be described as a performative aesthetic project toward the resurrection of Andean cultural autonomy. Another crucial, and consistent, presence within the novel is that of the anonymous narrator who is in conversation not only with the Andean mythological characters, but also engages in multiple instances of intertextuality that make his presence an invisible, yet active, one.

The narrative structure that is a constant throughout all eleven retablos is the presence of our anonymous narrator whose voice guides the entirety of the work that shifts between genres and thematic concentrations. If a single summary pertaining to all retablos had to be given, I would prioritize the role of the narrator and his search for a new form of cultural aesthetic expression. Thus, my ideal summary sounds like the following: El pez de oro narrates an anonymous narrator's nomadic journey for a language of Andean sensibility and aesthetics that is able to re-connect him to the PreColumbian Andean world. 
The consideration of the narrator as an overarching leitmotiv within El pez de oro can be seen through his constant presence within the disjointed retablos, and contains a symbolic role as a representation of the future Andean subject whose self-expression is still unformed and conflicted. The narrator assumes an aspect of collective value in the ways in which his search for expression must be excavated through the collective mythology of the Andean past confronted with realities of the modern Andean subject. His collective voice, as assemblage of the Andean past, present, and aspirations for the future, heightens his divided identity through his lack of corporal existence. Containing a voice, this narrator-protagonist lacks a physical body, besides a passing, and symbolic, reference to his flesh (El pez de oro 205). The presence of the narrator is seen as an omniscient cosmic voice that journeys through the Andean underworld. Vicky Unruh in Latin American Vanguards lends a similar summary of the role of our unseen narrator:

The work narrates a young writer's journey to a pre-Columbian past where he seeks to resolve the conflict of competing cultural traditions that hamper his creativity...El pez de oro's principal narrator is a would-be writer searching for a language that will express his culturally conflictive experience, a quest that leads him to the Andean indigenous underworld. (140)

Unruh summarizes how the protagonist functions as an omniscient witness allows for a more balanced and reflective function for the reader:

This artist assumes a privileged, cosmic position... and affirms the totalizing capacity of aesthetic activity to encompass humanity's past, present, and future... the speaker assumes a superior cosmic position and vision, witnesses creation, and, asserting that he is the "total" man balancing centuries of humanity in his voice, constructs a self-affirmative poetic persona...and whose mind is forged in the tongues of prophets. (72) 
The narrator's cosmic position allows the narrator to weave between genres, languages, histories, and mythologies with ease. This cosmic voice allows a reading focused on other narrative aspects or theoretical approaches.

Countering the summary regarding fiction, a reading focused on the role of language would present a definition of El pez de oro as an exploration into the development of Andean aesthetics within the colonial and post-independence period that lends a linguistic hybridization of baroque Spanish alongside the vernacular languages of Quechua and Aymara in hopes of allowing the possibility for a new American language enabled by the Andean voices themselves. An ethnographic, historiographic, or anthropologic reading would yield a vastly different perspective. What Churata's structure allows for is a constellation of differing sociopolitical factors pertaining to the Andean American identity without allowing one factor to impose itself over the others. It remains a novel open to multiple readings based on retablo, style, genre, period, and the cultural experience of the reader.

El pez de oro opens with a critical essay regarding the possibility of a new heterogeneous language grown out of the literary tradition of the cronistas and indigenistas ("Homilía del Khori-Challwa"). Other retablos put this possibility of the new American language into practice by focusing on the Andean tradition of orality and mythology ("El pez de oro," "Mama Kuka," and "Puro Andar"), mythological poetry ("Morir de América"), mythological prose ("Piedros de Piedra"), and performative textuality ("Morir de América"), some retablos contain a more symbolic biographical approach, ("Los Sapos Nengros") while others continue to probe the Andean underworld through a hybridization of history, ethnography, and mythology ("Pachamama"). 
What these different retablos help to argue is that El pez de oro is a multi-generic, multi-styled novel that does not exist under one specific literary categorization.

Usandizaga notes how the change in genre, style, and themes act toward the formulation of a dialogic novel whose categorization remains blurry:

La pregunta que se presenta...es la de la organización de la obra, que resulta difícil catalogar...El pez de oro es una obra transgenérica: no es novela, aunque tiene un hilo narrativo, y no es ensayo en el sentido clásico aunque su estructura dialógica entre diferentes sujetos, formula preguntas y escenifica el encuentro entre diferentes respuestas para llegar a un conocimiento que se construye en el texto. Tampoco es un libro de poemas, pero está lleno de poemas a veces muy cercanos a las formas tradicionales andinas. (93)

This lack of categorization is heightened when Churata's narrator begins a journey into metafiction, poetry, orality, and articulated sounds of nature. Despite taking away from the popular circulation that the novel may have reached if contained within a more formal form and content, Churata's alternative approach to textual production and representation is a unique interpretation of cultural heterogeneity that attempts to parallel European forms of myth, textual production, and historical representation with their Andean counterparts that create a cultural tension that takes place on the page. Yet this tension is not one of equal resistance. While parallel in their representation, it is still the dominant European narrative models that have historically attempted to dominate and erase Andean cultural autonomy. Through his writing, Churata sought to distinctly separate European from American concepts. Usandizaga notes:

Churata propone expulsar lo español para recuperar otra españolidad como algo propio tras asimilar lo indio, e imagina en su diálogo con Sancho la posibilidad de que esto no funcione, para hacer ver que esta posibilidad negativa representaría la negación de América y la positiva, en cambio, una regeneración. (85)

This regeneration of Andean mythology, language, and historical memory does not 
attempt to reclaim the Andean past as much as pave a path for the autonomy of an Andean future and self-representation of historical memory within the legacy of colonialism. This regeneration is also what sets Churata apart from fellow writers in the period of indigenism, the indigenistas.

El pez de oro came about during the most politically and culturally charged period of contemporary Peruvian history. While the formation of the Peruvian literary tradition has always been concerned with the reinvigoration of Andean or Mestizo cultural identity, these regional and cultural reflections became revitalized in the first decades of the twentieth century under the umbrella of indigenism. While Peruvian writers, politicians, and intellectuals who emerged within the tradition of indigenism shared a goal of cultural reinvigoration, their methods varied. First ignited by Inca Garcilaso's Los comentarios reales and Guaman Poma de Ayala's Nueva crónica y buen gobierno during the period of direct colonialism, historical and contemporary mestizo voices have always sought forms of cultural recuperation and colonial resistance through textual production. The more contemporary tradition developed during "un momento de auge en la evolución política, social y cultural del Perú” (Travesía de un itinerario 7).

The sociopolitical influence of indigenism gained renewed momentum within the latter half of the nineteenth century inspired by Peruvian intellectuals such as Manuel Gonzalez Prada, Luis E. Valcárcel, and Clarinda Mato de Turner's Aves sin nido before being modified to the more modern content by a new wave of indigenistas: José Carlos Mariátegui, César Vallejo, Carlos Oquendo de Amat, José María Arguedas, Martín Adán, 
and, our author, Gamaliel Churata. ${ }^{4}$

Born Arturo Pablo Peralta Miranda on July 19th, 1897 in Arequipa, Peru, Gamaliel Churata spent much of his youth in Puno before settling there in 1906 (Travesía de un itinerario 215). While beginning as a typesetter, Churata soon found himself writing, editing, and publishing for various periodicals during a period of serious economic and industrial boom in the Andean region during the first decades of the twentieth century. Churata, then still known as Arturo Peralta, began his literary career as a commentator first for El Siglo in 1914, and then held a recurring role in the periodical La voz del Obrero between 1915 and 1917, before moving on to write under the Pseudonym Juan Cajal in various magazines and newspapers between 1917-1919. The use of pseudonyms was heavily used by Peralta, who was known to have been published under at least five different names (Arturo Peralta, 1915-1917; Juan Cajal, 1917-1919; Gonzalez Saavedra; Gamaliel Churata, 1926-his death; y El Hombre de la calle, 19551958).

Throughout his various personas, Churata began an early literary career as a social critic who challenged ideas of mestizaje and argued for a new option for the regeneration of Andean cultural autonomy and the role that indigenism would play within this process. These editorials were often social and political, and while his writing style was stylistically singular, they did not yet contain the multiple levels of aesthetic and thematic tendencies which would go on to define his legacy.

\footnotetext{
${ }^{4}$ While hardly ever mentioned alongside other major figures of indigenism, the role of Churata during this period was of equal importance where Churata's publication Boletín Titikaka was highly influential in developing the debate on the role of indigenism and its varied conditions between the subaltern altiplano and the cosmopolitan capital. See Cynthia Vich's Indigenismo de vanguardia en el Perú: Un estudio sobre el Boletín Titikika. Fondo Editorial de la Pontificia Universidad Católica del Perú, 2000.
} 
Despite his early success and reputation throughout Peru, Gamaliel Churata's literary career did not fully blossom until him and his brother, Alejandro Peralta, debuted their own periodical Boletín Titikaka that ran from 1926 to 1930. Boletín Titikaka was one of the principal periodicals concerning indigenism during the late 1920's along with José Carlos Mariátegui's Amauta. It was also during this period of transition into his own periodical where our author began his permanent shift into the pen name "Gamaliel Churata" - the name he would publish under until his death in Lima in 1969.

The adoption of the pen name Gamaliel Churata is not random and provides insight into the cultural positions that drove Churata's writing. "Gamaliel" was a biblical figure of high authority within the Jewish Sanhedrin, an assembly of Israeli intellectuals, whose student, Paul, would go on to be one of Christ's apostles. Having grown up under devout religious parents, the role of biblical theology and Occidental philosophy is apparent throughout El pez de oro and was surely a consideration when adopting this name. "Churata" in Quechua means "el iluminado," an idea of a nobleman of venerated status. Yet this status of a Churata must be lent by a superior being, a deity or high shaman. The coexistence of these cultures within his name, roughly translated to "Gamaliel the Wise" or even "The wise teacher," orients the reader into an exploration of the coexistence of two distinct cultural worldviews.

Churata grew up within the context of indigenism where Boletín Titikaka played a predominant, and underrepresented, role in facilitating communication between the subaltern Andean altiplano of Puno and the cosmopolitan capital of Lima. The newspaper boom in Puno during the period of indigenism and developing industrial modernity provided many subaltern voices a space for cultural reflection and the expression of their 
own reality in a rapidly changing socioeconomic environment. The representation of reality constitutes the points of departure for the indigenistas.

Indigenism grew from a very homogeneous standpoint where Gonzalez Prada and Valcárcel envisioned the resurrection of the indio as a result of violent conflict against the colonizers. Luis E. Valcárcel, a criollo himself, was not shy in labeling racial heterogeneity a deformity, "nace del vientre de América un nuevo ser híbrido: no hereda las virtudes ancestrales sino los vicios y las taras. El mestizaje de las culturas no produce sino deformidades" (107). This idea of representation, hybridization, and the question of heterogeneity is one that divided the indigenistas. While some of the earliest figures were less willing to relinquish the need, or inevitability of heterogeneity, others developed indigenism into a heterogeneous social and cultural movement concerned with practices of social and political transformations enabled by a period of industrial modernization.

These transformations, due in part to the increasing role of technology and the ease of communication through the construction of a highway system throughout the Andean region, enabled regional conceptions of intellectualism and cultural practices to communicate, mingle, reflect, and grow where marginalized groups could now reflect on, and represent, their own cultural identity. These new regionalist identities grew, in part, due to their resistance to the centrality of Lima where their cultural identity was no longer tethered to political, societal, or intellectual developments in the capital. That is to say that indigenism grew in part as a response to the rapid process of modernization that had drastic effects on subaltern reality. One of these effects was the increased lines of communication as a result of the new highway system and the newspaper boom which facilitated communication between the cosmopolitan and the subaltern interpretations of 
Peruvian reality.

Jorge Coronado in The Andes Imagined summarizes how indigenism made subaltern communities conscious of their cultural identity, and how this new consciousness of cultural difference enabled critical developments in reclaiming their cultural agency:

These transformations include...the subsequent emergence of new subjects into the nation, the region, the city, the neighborhood, and other conceptual units of communal and individual identity. These transformations triggered subaltern subjects to lay claims on the societies that had previously marginalized them and, in most cases, persisted in doing so. (2)

Coronado goes on to call this new consciousness of identity and its subsequent movements as "pressure from below" (ibid) where marginalized or subjugated cultural subjects begin the process of reclaiming their own agency through their own cultural infusions alongside European imports of culture and technology.

The arrival of technological imports at the beginning of the twentieth century also brought with them European cultural and artistic developments and philosophies which mestizo intellectuals, such as Mariátegui, quickly adopted as an integral subject in their absorption of modernity. Riccardo Badini in "La ósmosis de Gamaliel Churata" explains the role of European models of thought and artistic production as imposed over the social model of indigenism that offered an attractive alternative to existing models of indigenous expression, “el pensamiento indigenista ejercita una atracción y representa una posibilidad...de nuevas formas de expresión artística" (345). These artistic expressions while encased in indigenism were rooted within European models of social and artistic revolution. Inspired by ideals of Marxist revolution and the aesthetic goals of modernism and the avantgarde, new Andean and mestizo voices found new forms of 
expression.

In the age of adopting European industrial and artistic developments arose a sociocultural space for the emergence of a new cultural subject who enabled a new cultural literature able of restoring Andean historical and cultural memory through adopting and inverting European models of narrative representation. This new space was occupied by many emerging Peruvian voices who balanced heterogeneous textual production and reformulated Andean identity in the first half of the twentieth century. Indigenistas who occupied this more heterogeneous role of racial or artistic hybridity include the avantgarde poetry of Cesár Vallejo, the Marxist critiques of José Carlos Mariátegui, and the fiction of José María Arguedas. While Churata engages in ideas of mestizaje, he did not represent the Andean subject from below in the way of Arguedas and a few other contemporary figures. Rather than depicting the return to a utopic past, or the depiction of the utter domination of the Andean subject within his own territorial space, Churata approaches heterogeneity, mestizaje, and hybridization from a more aesthetic perspective. Churata was engaged with aesthetic heterogeneity rather than racial mestizaje. For Churata, Andean representation had to circulate around and within the Andean spirit, Usandizaga summarizes his vision well when she says:

La obra de Churata se aleja de la mayoría de los indigenistas, que trataron de representar el mundo indígena; para él, el proyecto era conectar con el saber y la sensibilidad de ese mundo para escribir una obra que reivindicara los orígenes de los culturalmente mestizos como él y a la vez hiciera visible lo propiamente indígena fuera de los estereotipos ligados a la mirada externa, en la medida, claro, en que es posible evitar esa mirada por parte de un no-indígena. (El pez de oro 14)

This connection of "saber" and "sensibilidad" in a way that can properly capture the origin of culture, transformed through conquest, had to rely on more than European 
models and demanded a presence for Andean self-representation both in terms of form and content. This demand required a return to the pre-Hispanic oral tradition, Andean narratology, Andean mythology, and historical memory, placed alongside European concepts of historiography and narratology while maintaining the Andean subject as the center of a new cultural and historical coexistence. A narrative model such as this could not rely on common genres of prose, poetry, fiction, or history and instead had to create its own textual space guided by Andean mythology. In Latin American Vanguards Vicky Unruh notes, "essential for this new culture would be the emergence of a new American being, variously designated as the new 'cosmic fetus,' the 'new human soul,' and the "matrix race'" (131). The type of hybridization that intrigued Churata was an aesthetic friction that produced a new subject who, rather than a mere racial mestizo, was equipped with cultural tools that engage the possibilities of a "cosmic fetus," enabled through a reconsideration of cultural conflicts. A principal cultural conflict that Churata seeks to resolve in search for this new human spirit holds roots in the cultural conflict of language and aesthetic representation, orality and textuality.

While scholars such as Coronado focus on the role of "technolification" (2) and indigenism at the beginning of the twentieth century, traces of this cultural conflict between the Andean oral tradition and the imposition of the European import of the book are often traced back to the encounter between the "bastard Inca" Atahualpa and Francisco Pizarro in Cajamarca in 1532. There, Pizarro gifted a bible to Atahualpa who, upon placing it against his ear and hearing nothing, threw the book to the ground. Insulted by the gesture and seeing the book draped in a cloud of dust, Pizarro took the act as a sign of war and fought violently against Atahualpa and the Incas that ended with 
Atahualpa's execution, the extraction of natural resources, and, ultimately, the evaporation of the Inca Empire.

Along with the extinction of the Inca empire was the erasure of their historical memory and archives which made a return to the past an impossible task. As an oral culture with vastly varied forms of historical representation in the form on knotted khipus, the only traces of an Inca past were inscribed into the bodies and minds of descendants and the verbal artifacts passed on through the oral tradition. The inability to impose the archive of the body, performance, and Andean historical memory over European forms of textuality and documentation left the Andeans as a culture without a past due to the imposition of European modernities, "si la articulación del pasado es prohibido por presiones políticas o religiosas, entonces el pasado se borra de la memoria" (Astvaldsson 617). As I will argue later in this thesis, the erasure of historical memory created a new cultural space for the re-creation of historical memory through a reinvigoration of Andean myth and narratology executed in the retablo "Pachamama." While the anecdote of Atahualpa and the book runs throughout the historical records of both cultures with differing accounts of what was said and who began the violence, it nonetheless acts as an encapsulating metaphor for the cultural conflict surrounding the act of textual production, historical representation, and the distribution of cultural systems of knowledge through modes of inscription and archive. This conflict between imposed and native modes of production and memory have persisted throughout the history of Peruvian book culture, in terms of production, distribution, archive, authority, authorship, as well as form and content. A consistent presence from Atahualpa to Inca Garcilaso up to the indigenistas, the act of Andean textuality and historical 
representation seems endlessly at ends with the tyranny of the page and has sought new modes of representation through adopting new technologies as their renewed forms of cultural production. Examples of contemporary technolification and Peruvian textual production as a decolonial activity continue into the modern context, unconsciously driven by textual performances of colonial resistance dating back to first contact.

Drawing on European forms of expression and guided by a brightened sense of decolonial ideology, authors such as Churata sought unique inversions to their textual practices that would confuse and detain the evolution of the book within Peru. In Book History through Postcolonial Eyes, Robert Fraser lends a perspective on how postcolonial textual production served as a form of decolonial consciousness:

Book history, I believe, cannot and should not be constructed as a process of inevitable, irreversible evolution, or even as the product of the intelligently ordered design. It is a battlefield in which technologies slog it out and voices strain to be heard, and where economics and commerce vie or conspire with the needs of self-expression. (105)

This "battlefield in which technologies slog it out" is very apt to this context where a rapid influx of European industrial and cultural technologies clashed with the "ordered design" (ibid) of the oral tradition and traditional literary or narrative practices.

While originating as a political response to swift changes introduced through modernity and industrialism, indigenism soon shifted to include more aesthetic and artistic methodologies. From its political roots and artistic practices, indigenism can easily be classified as "both an oppositional force and an establishment set of practices" (Coronado 9). Coronado lends a wide interpretation of modernity and indigenism as a movement first based in forming oppositional politics before engaging in new forms of aesthetic practices whose greatest expressions came not from fiction, but rather from 
other forms of media and technology. The place of Gamaliel Churata among the indigenistas was of seminal importance during this period, yet his contributions to the development of indigenous thought and the reinvigoration of Andean identity through decolonial textual practices have since been disregarded and forgotten. Such an omission is made all the more perplexing considering that Churata was fully engaged in political as well as aesthetic ideological practices o indigenism.

The altiplano city of Puno presents an interesting subject when examining the role of modernity and industrialization in a subaltern region considering its stature as a locality of indigenous revolution. Its position as a predominantly indigenous Andean region made the rapidly evolving subaltern city a hotbed of anti-colonial, anti-modern sentiment. The attachment of Puno to culture, nature, and tradition is not only due to its isolation from Lima, but also its location where the origin of Andean cosmology sits within its reach.

Andean mythology revolves around the idea of Lake Titicaca as a cosmological meeting place of cultures, worlds, and histories, "lago Titicaca — origen y cementerio de todas las culturas andinas, en el fondo del cual viven los antepasados de toda la población del Altiplano" (Velasquez Garambel 61). Churata maintains allegiance to this cosmological origin that allows the Andean subject to feel a deep connection to their nature, a connection that has become broken. By maintaining the narrative around Lake Titicaca and searching for origins through language, a connection between subject, place, and culture can be more easily attached.

Given its mythological standing as the origin of the known universe, it makes sense that Puno has often been the center for Andean rebellion and a recuperation of 
indigenous rights. While contemporarily othered due to the expansion of communication during the period of modernity and the rapid migrations to Lima, the colonial period in Puno was marked by a period of economic and regional independence enabled by the proliferation of productive mines. Puno also served as the Southern base for the Tupac Amaru II rebellion before a final nineteenth-century stand as a site of colonial resistance in the Juan Bustamante Dueñas rebellion in 1863. José Tamayo Herrera allows how such indigenous movements shared the ideal of a reinvigoration of indigenous rights, and a reconstitution of the indigenous subject as being in control of his or her own cultural and political representation:

El periodo de más intensa vida cultural y creadora que ha producido el Altiplano en el siglo XX, con el surgimiento del indigenismo como corriente de ideas, de la consolidación de una "intelligenista" puneña que trasciende por primera vez el ámbito de la región, hasta hacerse oír en el Perú y fuera de él. (87)

Acting as the center of colonial resistance and Andean cultural resurgence from colonization into the twentieth century, Puno became culturally and intellectually isolated from the multicultural capital of Lima and was able to establish a sense of regionalism within the subaltern region. Despite internal conflicts regarding the role of indigenism and cultural isolation, their relative isolation did not exempt Puno from the serious social and economic impacts brought about by the period of modernity. A period of expansive social and economic upheavals, including the construction of a new highway system and other technological imports, opened Puno to a more rapid process of open communication and modernization.

As a subaltern center for indigenous expression, Puno quickly became a center of communication and political activism. The migration of the avantgarde into Latin 
America corresponded with the same migration of modernity and the subsequent changes to Peruvian, yet more specifically Andean, cultural and economic realities. As modernity and industrialization began to grow within Peru, so did the avantgarde cultural scene marked by the emergence of such figures as: Martín Adán, Carlos Oquendo de Amat, César Vallejo, and of course, Gamaliel Churata. Carlos Oquendo de Amat emerged as an important figure here as he was one of the principal vanguardistas in Puno who approached modernity and indigenous representation in, equally unconventional yet, distinct avantgarde forms. Oquendo de Amat approached the problem of modernity in 5 metros de poemas through a focus on avantgarde forms which he stretched to their limits in order to present them as opposed to a reflection of Andean reality.

Yet Carlos Oquendo de Amat was not against technology, rather he was fascinated by its potential. Oquendo de Amat was obsessed with the idea of modern technology as an abstraction within subaltern reality and he searched for new forms that the object of the book may take in the future. The word "ascensor" literally ascends the page vertically, one page calls for a 10-minute intermission, even another directs the reader to "abre este libro como quien pela una fruta" in reference to the book's format which can be pulled out to cover 5 meters, hence the name (Oquendo de Amat 1969). ${ }^{5}$ This strategy by Oquendo de Amat is wonderful in exposing the change in aesthetic tastes brought about through modernity and how the technology of the book is not adapting to meet these new aesthetic needs. As a means of revealing this new disconnect between

\footnotetext{
${ }^{5}$ As a variation of the contemporary "pop-up" accordion book meant to be extended, this reference does not contain page numbers, only measurements.
} 
new and old aesthetic technologies, the reader must be re-oriented within each page where words are scattered, backward, diagonal, and with divided by large white spaces.

Much like Atahualpa, Oquendo de Amat saw the book as an alien product that has no rationale within the traditional Andean aesthetic. More, the object and form of the book have seemingly stayed outside processes of modernity. While railroads, highways, printing presses, and buildings are rapidly evolving into new forms, the object of the book remains a static repository of words. Endlessly intrigued by the possibility of future technologies, Oquendo de Amat represents a popular strain within the Latin American vanguards of exploring processes of publication, and the use of space within the page to help push the object of the book to its modern formulaic limits.

While Churata was not as invested in exploring form the same way as Oquendo de Amat, he was intrigued by the idea of futurism and "technolification" in regards to traditional forms of cultural production. Churata's unique interpretation of modernity as an aesthetic project manifested in similar forms of textual experimentation: pamphlets, magazines, performative texts, plays on form, and a reinvigoration of Andean mythological figures as literary characters. Outside the unique form of language he would come to be known for, the role of Gamaliel Churata within the period of indigenism in Puno is well-known and he has been credited, from both Bolivia and Peru, as a vital cultural and political component for the development of indigenous rights in the region. Besides his personal activism and later writing, the role of Churata's periodical, Boletín Titikaka, during this period was influential, yet ultimately damning to the life of Gamaliel Churata. 
Throughout all 34 issues of Boletín Titikaka, Churata and his brother opened up a series of dialogues with other Latin American intellectuals concerning the development and social function that indigenism would play as a means of repelling colonial impositions and beginning to reformulate manners of allowing the indio to express himself through his own aesthetic models. Churata's publication was soon on the national stage where names such as Valcárcel, Vallejo, More, Mariátegui, and even Jorge Luis Borges were published within the first few issues. More than a platform for selfexpression, Boletín Titikaka was a testament to the function of new lines of communication that allowed such dialogues between the metropolitan capital and the subaltern Andean region. Boletín Titikaka begged the cultural question of what role the subaltern subject would play in the development of modernity and the expansion into globalization. These considerations of the representation of the Andean subject within their own future developed during the period of indigenism which began as a political ideology before being transposed into a literary practice.

Through his editorial postings in Boletín Titikaka and his constant correspondence with the indigenistas, Churata had unintentionally aligned himself with José Carlos Mariátegui's Marxist Party, bringing himself unwanted attention from the newlyimplemented Peruvian government. With the fall of Augusto Leguía under a coup d'etat by General Luis Miguel Sanchez Cerro on August 22 ${ }^{\text {nd }}, 1930$, the political and educational reforms put in place by Leguía in Puno were reversed where socialist revolutionaries and movements were made primary targets for isolation, imprisonment, and exile.

By 1930, Churata had already accumulated a pile of texts attesting to his socialist 
sympathies and was soon characterized as a socialist and was marked for investigation. Carlos Medinaceli, a Puno journalist and confidant of Churata once wrote, "lo cierto es que nuestro amigo hoy es un marxista convencido y militante y literalmente, un indigenista feliz" (Monasterios 227). Such a characterization damaged the reputation of Churata in Puno who was soon forced to resign from his post at the Municipality and would soon go on to shutter Boletín Titikaka forever. The end of Boletín Titikaka came abruptly due, also, in part to personal turmoil in the life of Churata, as well as Mariátegui. Within a span of a year, Gamaliel Churata lost his intellectual peer in José Carlos Mariátegui, two of his three children, Teodoro and Clemencia, along with his wife, Brunilda, all due to illness. These personal tragedies deeply affected Churata, who struggled through 1929 and only managed to print one issue of Boletín Titikaka in 1930, an issue dedicated to the life of José Carlos Mariátegui, before he and Alejandro shut the press permanently.

After the democratic election of Sanchez Cerro in 1931, Gamaliel Churata was briefly imprisoned and had his home ransacked. At least two full manuscripts were confiscated never to be seen again. Churata was then incarcerated for 38 days in Puno before a self-imposed exile to La Paz, Bolivia in April 1932 (Gonzales Fernandez 218). After his migration across Lake Titicaca, Churata made a new home for himself in La Paz, Bolivia where he continued to work in various educational and political field while working on El pez de oro until its publication in 1957.

The first anticipated publication of El pez de oro was slated for 1932 in La Paz, Bolivia by the Subsecretaría de Prensa, Información y Cultura. However, the printing press was raided and the original printed copies were burned by governmental fascists, 
delaying its publication for another 25 years (El pez de oro 147). Churata was to remain on the southeastern shore of Lake Titicaca working for various publishing houses as a typesetter and editor while also working as a secretary and speechwriter at the Bolivian Office of Information and Culture until returning to Peru in 1964 to search for his lost manuscripts.

This chapter has attempted to create is a historical and theoretical context in which the production of El pez de oro and the life of Gamaliel Churata can be situated and understood. While Churata appealed for a distancing of autobiographical symbolism from serious textual study, "no se quiera ver el desarrollo dramático de sus diversos Retablos, ni en el hilo magnético que les da unidad, simbolismo autobiográfico" (El pez de oro 147), his novel disintegrates if we reject the importance of the cultural climate of the age of indigenism.

The issue of modernity in Latin America is not a problem of the twentieth, or twenty-first, century. The problem of modernity as cultural and political impositions dates back to the first encounter of the European and Andean worldviews. Carl Schmitt in The Nomos of the Earth in the International Law of the Jus Publicum Europaeum divides modernity into two categories: pre- and post-1500. Through this division of pre- and post-modernity, it can be argued that the pre-modern cultural world was one of diverse worldviews within one locality while the shift into a post-modern world, not related to postmodernism, can be constituted by the emergence of a more homogeneous and monotheistic worldview where any deviation from the dominant norms was considered barbaric and primitive. Such a fracture in ideas regarding the constitution of the past created a hierarchical structure where imperial colonial voices held the authority to erase 
the past and plant their own explanation of human origins through language, writing, and history. What this lost past represents is more than a decoupling of subject from history and culture, it allows an infinite number of possible pasts to be conceived and idealized. Within this blurred image of the past, many indigenistas began to write their own idealized image of a nostalgic pre-Columbian era.

What other voices of indigenism, such as Churata, envisioned were processes of cultural hybridization going into the future rather than a revival of a lost past. Churata sought to reconfigure the colonial relationship where cultural and racial dualisms could find resolution in hybridity going into the future rather than a symbolic return to an imagined past. The perfect cultural porridge for Churata that enabled the resurrection of the Andean world through a cultural hybridization of language and mythology that enables the creation of a new American subject where the pre-Columbian past becomes an inherent aspect of the present Andean subject. Only by means of making the Andean subject an active culture producing agent within his present reality can the formation of an American subject as a heterogeneous identity become a reality in the Churatian future. The first step in the formation of this reality comes from a revival of language as a culture producing tool. 


\section{"Homilía del Khori-Challwa" and the Possibility of American Literature}

The articulation of American identity, language, and literature was a theme which

Churata addressed in his writing for more than three decades. Some of his first publications during the 1910 s present the problem of American identity as a largely aesthetic one, and in an essay entitled "La América no existe" published in La calle in 1936, Churata asserts the non-existence of America:

América no es sino el desdoblamiento de Europa, la conquista de campos vastos para la industria extractiva y de mercados vírgenes para el comercio, pero siempre como fénomeno simplemente europeo...América es solo eso: La Colonia de Europa; la otra, la América que los ilusos Americanos soñamos, hay que extraerla de la gleba fecunda en que hace cinco siglos dormita. América, pues, no existe.

This essay, written a few years into his exile, encapsulates Churata's idea of the invention of America as it stood in the moment of twentieth-century modernity. As he saw it, America was a colonial product of an imperial project whose main goal was the seizure of lands for the extraction of natural resources and the creation of new markets within untapped subaltern regions. America, as an invention of capitalism and modernity, lacks the capacity to represent American identities given their inherent distance from the language and origin of these cultures. While Churata makes it clear, and repeats throughout El pez de oro, American identity and American Literature do not yet exist under the imposed hierarchical construction of power regarding race, politics, economy, language, and history. They remain a distinct possibility in the future when produced through processes that return the Andean agent as an inherent creator within this identity where their language and history remain alive and active.

The opening retablo of El pez de oro, "Homilía del Khori-Challwa" ("Homilía") offers a theoretical and practical approach to Churata's vision for the existence of an 
American Literature as dependent on a new American language. In this extended retablo, focus shifts between his critical non-fiction essay regarding the possibility of a renewed heterogeneous American language and his aesthetic considerations of the mythological Andean world, before narrating the origin of the central narrative arc - the birth of KhoriChallwa in the depths of Lake Titicaca. The origin of Khori-Challwa functions as Churata's principal symbol for the engenderment of a new Andean subject - a symbolic role that extends throughout the entire work. Khori-Challwa exists as the progeny of Khori-Puma, or El Puma de Oro, who lives in a cave in the deep waters of Lake Titicaca where he huddles in fear for his survival. Khori-Challwa's mother, La Sirena del Titikaka, acts as a symbol for the enticing call that modernity offers while veiling over her dangers. After introducing the engenderment of Khori-Challwa and explaining to him the situation that his culture finds itself in, "Homilía" concludes with our narrator inciting Khori-Challwa to fight for cultural revival to ensure the survival of himself, his father, and the memory of dead Andean ancestors, Los Chullpas.

Through a mixture of critical analysis and symbolic mythology, Churata seeks to reveal the necessity for the revival of indigenous language as a means of reviving shades of the lost Andean worldview that will allow the new Andean subject to find his voice, agency, and future expression. Despite the presence of this symbolic mythological narrative, the majority of the retablo is dedicated to the textual analysis of Churata regarding the formation of the Peruvian literary tradition as a possible strain of the American literary tradition as they both draw breath from the same search for origin. As a means of investigating the possibility of reviving traces of origin through language, Churata focuses on the role of the cronistas and their infusions of Andean 
traditions and language into their experimental texts. Beginning with the role of language in Inca Garcilaso's Los comentarios reales and Guaman Poma de Ayala's Nueva crónica $y$ buen gobierno as decolonial textual options for this new language, Churata then puts his theory for cultural hybridity into practice by beginning to fuse Andean mythology and language as he introduces the central narrative arc. Taking influence from both colonial figures, Churata offers his own possibility for the new American language, one that draws on Andean aesthetics while simultaneously re-casting European discourse in an Andean cáscara, or shell. Through enveloping Spanish narrative and aesthetic into an Andean perspective, Churata allows a new language which restores a sense of cultural agency to Andean and mestizo identities - Quechumara.

I will go deeper into a proper definition of Quechumara later in this chapter, but for now it is important to consider that Quechumara, a term coined by Churatian scholar Mauro Mamani Macedo in Quechumara: Proyecto estético-ideológico de Gamaliel Churata, is the textual practice of hybridizing vernacular aspects of Quechua, Aymara, and dialectic infusions into the dominant language of Spanish. More than cultural hybridity, this use of language functions as a form of resistance against colonial cultural impositions. This function of language as resurrection and resistance enables new agency within modern Andean subjects, as well as opening a door for the consideration of El pez de oro as a strain of a minor literature.

In this section, I will argue for the existence of a language which enables the creation of an Andean American Literature by first lending Gamaliel Churata's theory regarding the possibility of an Andean American language developed through the context of the cronistas up to the period of indigenism that Churata investigates within 
"Homilía." Drawing influence from the cronistas, Churata then begins to experiment with his own aesthetic project toward the constitution of a language that connects Andean subjects back to their self-expression.

As mentioned at the beginning of this chapter, while Churata was engaged with an aesthetic project more than a historical one, his goals are still very much grounded in history and the search for a resurrection of Andean origins as they once were. Despite his understanding that any Andean future entailed a sense of heterogeneity, Churata saw that this future required a constant presence of conflict, tension, and resolution. While many indigenistas saw cultural and racial tensions as unresolvable, Churata saw that these tensions could produce new culture producing agents. As Helena Usandizaga notes, " $E l$ pez de oro reclama para el indígena una capacidad de generar cualquier producto cultural, algo que no se cumple solamente por las condiciones sociales" (42). More than fusions of racial, cultural, or political categorizations towards a new American identity, Churata was intrigued by the possibility that aesthetics allow for the creation of a new hybrid American subject. It is within this aesthetic friction that came new unconventional hybrid forms that aligned Churata with the avantgarde.

Keeping in mind the role of aesthetics as a cultural friction, the cultural battlefield of Lake Titicaca is where the Andean population, and Khori-Challwa, must fight to maintain their cultural survival. For Churata, nature gives birth to origin, and through origin we lend ourselves a sense of cultural identity and consciousness. So necessarily, any fight for cultural survival should take place in the nature that constitutes their origins. The fight for cultural survival is a resistance against oncoming processes of 
homogenizing the nation-state which in turn threaten tradition, language, nature, culture, and origin.

In beginning "Homilía," it is best to keep in mind the development of two distinct narratives contained within the single retablo. The larger portion of "Homilía" comprises Churata's critical investigation of the possibility of the existence of an American language through the work of the cronistas, fellow indigenistas and plunges into the role of racial tensions in the period of colonization where the indio was reduced to a marginal, if even perceivable, cultural importance. The latter portion of "Homilía" represents Churata's dabbling in his new language practice of Quechumara while lending the mythical narration of the origins of Khori-Challwa who wanders through Andean history as a symbol for the revival of a true Andean representation. In this way, Churata probes the resurrection of the Andean world and the possibility of America through a revival of language as reflections of true origin. While the recovery and incorporation of origin and tradition into a modern concept occupies the deepest aspiration for Churata, this rediscovery is only first possible through an exploration of language as a reflection of origin. Myth, origin, and language find common space within the opening line of the novel where the narrator-protagonist addresses the title character, El Pez de oro (KhoriChallwa):

Por lo que en estos cuentos, si no son fábulas, o mágicas del Laykhakuy, ${ }^{6}$ de ti diga y de tu lago, lo que de ambos haya escrito hasta acá, o escriba en días venideros, ¿a quién pediré perdón, KHORI-CHALLWA, sino a ti, si soy lerdo, y cojo, y manco y como nadie conozco que arremeto en Kharkhas ${ }^{7}$ para horadar en quienes me falta cincel aunque pulsos no me faltan? (152)

\footnotetext{
${ }^{6}$ Guión: Superficialmente el embolismo del brujo. Neo. Caminos de acción de la voluntad mágica.

${ }^{7}$ Guión: Ay. Peñolerías. (An abundance of hankerchiefs.)
} 
Churata begins the novel by utilizing a few of his most common uses of language, direct address, and aesthetic description. The role of direct address is a constant as Churata endlessly seeks to forge paths between distinct worldviews, intertextual dialogues, conversations between the living and the dead, mythological battlefields, even introducing classical fictional characters as present, "aquí nos damos en bruces, Sancho" (199). Churata allows a constant dialogue between the past and the present in order to discover a new way of representing a modernized future, "días venideros." Yet the experimental and creative language that Churata engages is presented as handicapped and lacks the ability to represent this world in any sufficient description. The narratorprotagonist wallows in his inability to engender the world he sees. Yet this lack of communication is not from a lack of imagination, rather a lack of words. The narrator lacks the hybrid language he needs to properly express his hybrid reality.

The reference that Churata makes to Sancho Panza is no random choice as the narrator goes on to reference Miguel de Cervantes as a man who, while physically handicapped, never lacked words to give life to his imagination, "pero un manco como pocos picapedro: don Miguel de Cervantes y Saavedra lego de aulas y de órdenes, me enseñó...que allí los mancos no manquean y los cojos vuelan..." (152). What Churata acknowledges is that Cervantes was a Spaniard and wrote in his native tongue for a native audience. The handicap crippling our narrator is not a corporal one, but rather an aesthetic one. He struggles to represent an aesthetic that does not exist in the dominant language: "cómo es de generosa su manquera, si los kuikos ${ }^{8}$ Americanos nos escribimos al modo siniestro a merced de la mano que allá los suyos le cortaron" (ibid). Churata

\footnotetext{
${ }^{8}$ Guión: Kh. Clásico. Aborigen, nativo, indio.
} 
shows an early example of the analogies that he uses as a function of didactic representation where the indio remains handicapped in his ability to represent his world in an alien language that leaves the indio without a voice or representation within the national consciousness.

Native Andean systems of cultural and artistic representation fall well within the categorization of textuality, and even within the tangible object of a book, when defined by the gathering of information in a single repository toward the clarification of cultural understanding. Yet the Inca khipus, keros, textiles, tunics, and other non-western modes of cultural inscription remain indecipherable collages of differing size, shape, and color. To Western eyes, the role of colorful textiles weaved together does not provide a representation of language where the conveyance of cultural meaning or knowledge is lost in translation. Yet colonial authorities understood that Andeans did rely on these objects as representations of the past, both in terms of aesthetic traditions and as chronicles of past conquests.

The association between these cultural objects and their significance posed a threat to Spanish colonial rule, and they were soon singled out for erasure and destruction. Art historian Tom Cummins in "Colonial Image of the Inca" clarifies the colonial need to distance these cultural objects from their meaning as a means of acculturating the native Andean subject, "the intent of Spanish acculturation was to rupture the nexus between the objects, their designs, and the cultural arena in which they operated. The signifying unity in Andean art between context, object, and design was, by the late sixteenth century, under siege by the process of acculturation" (207). To the colonizers, any system of cultural representation had to fit well within the standards of 
European systems of representation, such as a bound book of alphabetic spelling. If they did not, they posed a threat to acculturation and conversion and were readily destroyed. In many ways, Andean cultural systems of representation were seen as objects of worship, idolatry, and sin. The diary of Cristóbal de Albornoz is extensive in its call for the destruction of these cultural objects which he describes as idolatry and provocative in allowing for Andean rebellion as the designs of different textiles were meant to recall specific moments in the past, specifically military conquest. ${ }^{9}$ The destruction of these cultural texts not only allowed for a reinterpretation of the Andean past through the imposition of a Western system of representation, it also signaled a destruction of the connection between native Andeans and the significance of their cultural objects. This erosion between cultural objects and their meaning led to an intergenerational degradation of Andean cultural survival as their self-representation and expression was increasingly replaced by external colonial impositions of meaning and Western interpretations of history.

Within the Western system of representation, the object of the book and written language constitute the most basic foundation for cultural identity. Historically, any culture attempting to proclaim its existence in the Western world must do so through literature, history, or any other form of textualized reality given its role as the sole tangible substance of cultural production. Such a reliance on literature as the substance of national consciousness has undoubtedly been altered in the age of rapid new technologies where the role of social media and social media allow for new considerations of identity

\footnotetext{
${ }^{9}$ Writing without Words edited by Elizabeth Hill Boone and Walter D. Mignolo allows for a larger contextualization on the modes of textuality and their cultural conflicts during the period of colonization in the Andes.
} 
ranging from nationality to gender to race. Yet remaining in the period of production concerning El pez de oro and the earlier colonial period, the lack of Western authority within historical Andean systems of representation have left the Andean culture without the modern tools to compose their own literature or state their own history.

Churata engages the Western idea of alphabetic documentation as the substance of cultural representation and existence when addressing the links between alphabetic textuality and its documentation in the object of the book, "en las letras, en la palabra, que se compone de letras, en el lenguaje que se edifica con palabras, si escritas, se contiene el órgano de expresión de una literatura; por lo que el punto de partida de toda literatura (y de todo hombre) está en el idioma que la sustancia" (ibid). If not able to sustain their traditions and history within their own language or cultural productions, Andean culture ceases to be an autonomous and relies on external models of cultural representation. By denying a space for Andean textiles, tunics, or other cultural products of cultural meaning, and by containing them to the physical body and orality, Andean history became supplanted by the more global medium of print and through colonialism.

The Andean lack of textual archive led to a disintegration of indigenous narrative and culture when placed against the colonial context of writing as the ultimate authority of representation and existence. Without this attainable history and being forced to accept colonial interpretations, Andean identity become to be defined through colonial texts and documents. From this, the subjects of the New World ceased to be Andean and would go on to become "indians" or "Americans." Yet their external classification as Americans hardly constitutes Churata's vision of America. For Churata, his America is not an imposed identity, it is rather an identity forged through dialogic heteroglossia where the 
new product is as dependent on Andean cultural components (language, myth, history) as much as modern ones, “América...no puede venir de las patrias coloniales, a causa de otro imperativo. Y es el de que la Colonia Española constituye la negación de la patria americana" (175). Churata conceived American identity, as it was, as an external representation that erased any trace of Andean aesthetic autonomy in favor of importing Spain to a new locality. The constitution of American Literature for Churata does not include the Andean in any manner, American Literature is Spanish Literature that rejects the role of the indio, "La voz del indio en la Literatura Americana tiene que poseer el destino de chuki ${ }^{10}$ y la galga, porque entanto permanezca agrilletado en la cruz, su bramido puede ser un torrente de lágrimas; no tisana de eméticos" (174). By reviving the cultural attachment of Andeans to their mythology, nature, and language, a new sense of American identity can emerge as one forged toward a true heterogeneous identity, "una posibilidad de Literatura Americana quedaría resuelta si los escritores Americanos pudiesen emplear el Aymara y el kheswa" (184).

José María Arguedas shares a similar sentiment toward the inclusion of Quechua as a means of allowing a more representative form of Andean expression: "Si hablamos en castellano puro, no decimos ni el paisaje ni nuestro mundo interior; porque el mestizo no ha logrado todavía dominar el castellano como su idioma y el kechwa es aún su medio legítimo de expresión" (26). From this we can see that most of the indigenistas were engaged in manners of reigniting Andean cultural agency through a reinvigoration of Andean languages, yet the level of inclusion that bilingualism was to play remained an

${ }^{10}$ Guión: Quechua. Lanza, estoque alfanje; tirapié, instrumento agrícola. 
open topic of debate that took shape throughout many of the writings of Arguedas, Churata, and Vallejo.

If we agree with Churata's proposal and accept that the language of a subject's imposed representation can be used to substantiate the claim for their existence, then the colonized Andean American subject is a person without a semblance of self-autonomy or identity. Churata rationalizes how the imposition of writing and Spanish erased Andean cultural autonomy, "los americanos no tenemos literatura, filosofía, derecho de gentes, derecho público, que no sean los contenidos en los idiomas vernáculos, ninguna literatura escrita y solo leyendas en literatura vocal" (152). Through a lack of a textualized writing system, Churata asserts that Andean cultural existence was thrown into question where the constitution of rights, culture, or existence were dependent on structures of writing to reinforce a textual over oral reality. The only means of recovering lost Andean reality and casting it in a new light was through assuming command over the tools of their oppression, namely writing. Or more specifically, the Spanish language.

The role of the language of the dominant culture in a postcolonial context presents obvious issues to autonomous cultural representation. Issues of history and identity as being defined from an external culture and language place the subordinated culture into a space of collective expression and value, "el caso es que nos empeñamos en tenerla valiéndonos de una lengua no kuika: la hispana..." (El pez de oro 153). When colonial texts regarding the New World collectivize and minimize Andean identity through imposing Spanish over the individual Andean subject and their experience, social agency is denied. By denying Andean identity expression in their own language, colonial texts 
silence the Andean reality and instill a new collective identity defined within colonial terms.

Churata acknowledges the irony of being forced to recognize his imposed identity, an imposition which is almost comically flawed through mischaracterizing Andeans as inhabitants of the West Indies, “...En ella borroneamos "como indios,” aunque no en indio, que es cosa distinta" (ibid). In the quest to assume agency over their own identity and shed their characterizations as "Indians," Andeans had to first assume control over the tools of their mischaracterization — textuality and the Spanish language. Within El pez de oro, Churata envisions a space for the recuperation of Andean identity by doing to Spanish what Spanish did to Andean languages, make them culturally mestizo, "será posible solo si resultamos capaces de hacer del español lo que hizo de nosotros: mestizos" (153). Rather than dismantling Spanish and attempting to return to a lost past, Churata envisioned a future language where the Andean aesthetic and the development of a heterogeneous literary cosmos could begin to take shape. In investigating how Spanish can be made culturally mestizo entailed an examination in how a mestizo subject could interpret or express his new mestizo language.

After exposing modern ideas of the American identity and its literature as invented colonial constructs and arguing that a new American identity can be re-invented going forward, "Homilía" begins to trace the recovery of Andean cultural autonomy to the beginning of Andean lettered production, namely the works of Inca Garcilaso de la Vega and Guaman Poma de Ayala. These figures stand out to Churata as they both engaged in possibilities of the American language by introducing distinct infusions of Andean culture into the Spanish historical record. By reviving the textual practices 
engaged by these colonial figures, Churata begins to formulate a new functioning aesthetic language that draws inspiration from these figures.

Beginning with an analysis of Inca Garcilaso's Los comentarios reales, Churata questions the function of Garcilaso's mestizo identity in allowing his a clearer path to cultural hybridity, "un mestizo puede germinar en nueve meses y salirse toreando. Un idioma no" (El pez de oro 153). Churata does not lean toward a belief that a racial mestizo contains a deeper ability to represent the Andean aesthetic or reality than criollos or indios, and argues that Garcilaso's transatlantic bloodline was not an advantage. Even though Garcilaso was a cultural and racial mestizo, a truly hybrid language cannot germinate within a single subject. Rather, this process requires a long process of engenderment:

Los idiomas vienen de un tiempo de trino: el de lactancia del Pithecantropo; se mezclaron después, contendieron con voces a ellos ajenas, asimilaron unas, chakcháronlas, escupieron otras, en fin, las amañaron a la índole de su gorjeo y a la idiosincrasia de sus medios laríngeos en no pocos siglos (ibid).

Rather than a racial hybridization, Churata saw an organic evolution of experience and experimentation with language as containing potential for the reconfiguration of Andean cultural autonomy, "el mundo Americano permanece reducido al silencio del indio, que se conoce por estupidez de la raza, por lo que los americanos celebramos, nada tiene que ver con la raza americana" (184). For Churata, mestizaje was an impossible project as racial hybridity did not offer any creative possibilities for cultural production, "cualquier mestizaje es imposible, mas hay alguno impasable; y uno — bien se lo ve en este libro es el del hispano y las lenguas aborígenes de la América" (972). If allowed a position of 
authenticity over other cultural hybridities, racial hybridization would erase all Andean cultural components while holding on to Andean identity from a faint strain of lineage.

A linguistic hybridity, on the other hand, in the shape of bilingualism could ensure the continued presence of Andean culture within the national culture. Since Inca Garcilaso's mestizo identity did not lend him a deeper understanding of the necessity for a new American language rather than race, Churata was critical of Inca Garcilaso's reluctance to engage in Andean language and forms of narrative structure, thus, maintaining a European model, "él que pudo y debió hacerlo en Kheswa, empleó, y con qué gracia teresiana, el idioma de su padre, ya condenó el de su madre a una interdicción punto menos que fatal" (153). Churata's textual analysis of Los comentarios reales puts into question Garcilaso's distancing from any form of Andean poetics in his alleged recharacterization of Inca history and doubts that his intentions were purely for the reinvigoration of Andean autonomy, and that they may have been for more personal gains. Despite doubting the intentions of Garcilaso, Churata agrees with Garcilaso when he acknowledges that the colonial textual archive was a battleground of rights, social hierarchies and confirmation bias more than a space for historical truth or unity:

Que la materia misma de su alegato se trocara en la fusta que el mundo anglojacobino hizo restallar en los pecados de España, bien que no porque él se supiera libre de otros semejantes, cuanto porque así aceleraba su liberación dentro de la órbita de sus intereses, casi resulta ajeno a las intenciones del Inka. Y acá bien se puede parafrasear a Quintana, diciendo: culpa fue del pecado y no del Inka Garcilaso. (157)

More than the personal interests of Garcilaso, his direct connection to Spain pulled Garcilaso away from reviving the Incan worldview where his ability to conjure Andean reality, past or present, seemed doubtful. Garcilaso's mestizo identity and attachment to 
Spain revealed to Churata that American Literature did in fact already exist yet it was under the name Spanish Literature, "a pesar de todo, si nuestra literatura no es Española, nada es. Porque americana de América, no; en manera alguna" (177). Spanish authority, culture, and language were dictating the terms of production for all literature emerging within the Americas.

The legacy of Inca Garcilaso allows for an interpretation of the first steps toward Andean decolonization through using textuality as a form of colonial resistance. More, he was credited with allowing processes and acceptability of Andean intellectualism. This same legacy is marked by Garcilaso's mestizo racial identity which is integral in any interpretation of his writing and in deciding if his motives were more altruistic or personal. Given the consistent central infatuation with his racial mestizaje, Garcilaso's textual practice of regenerating Andean cultural practices can be constituted as a racial option of cultural hybridity. Within this racial option of cultural regeneration, the role of race, class, and culture are taken into consideration when defining the limits of imposed colonial identity. The mestizo identity of Garcilaso was both a generational inheritance from his Spanish father, and an imposed identity given the Andean ancestry of his mother.

For Churata, the racial option of cultural regeneration lacked a connection to the idea of aesthetics as defining cultural identity and meaning, preferring instead an aesthetic quality. Churatian and avantgarde scholar Marco Bosshard notes Churata's distaste of racial hybridity, "Churata niegue el hibridismo 'en la sangre' y, sin embargo, lo haga valer en el plano estético-idiomático" (57). From this Churata began to search for an aesthetic and oral option of Andean cultural autonomy. 
Moving beyond Inca Garcilaso and the option of racial hybridity, the other possibility for cultural regeneration that intrigued Churata was one where the rebirth of the Andean poetic spirit can come about when orality can act as a vehicle of expression rather than representation, "Estos harawikus ${ }^{11}$ ya no se persiguen 'interpretar' al indio, buscan expresarlo, y expresarlo en ellos...Y es preciso que la voz india adquieria vigencia porque haya llegado la decisión fatal de su victoria sobre los elementos negativos que la soterarron (158). This new oral possibility sought to inflect Spanish with traces of Andean orality toward expressing the Andean condition in ways that escape translation. The fusion of these two conflicted forms is more appropriately expressed as a hybrid, rather than mestizo possibility. As Garcilaso forms the base example of the mestizo option of an American Literature, Guaman Poma de Ayala constitutes the possibility of an oral hybridity.

In the same way that Churata sought to create a new space for the encounter of differing origins, cultures, histories, narratives, and myths in the reclamation of the spiritual, ritualistic and cosmological life of pre-Columbian Andean culture, Guaman Poma de Ayala created a space of historical autonomy by uniting differing forms of narrative structure and expressing them as without having inherent contradictions in the representation of Andean history. ${ }^{12}$

\footnotetext{
${ }^{11}$ Guión: Kh. -Ay. Los que cantan, aedas, rapsodas, de la era inkásica

12 In Indios, mestizos y señores, José María Arguedas engages in an ethnological study of Guaman Poma and referred to Nueva crónica y buen gobierno as the single most important colonial Andean text regarding a full understanding of the colonial period (Arguedas 11). Much like Churata, Arguedas was enthralled with Poma's manipulation of Spanish toward the infusion of native language and the integration of selfrepresentation regarding the Andean world.
} 
While the reputation of Poma was just beginning to blossom during the period of production regarding El pez de oro, it would not be an exaggeration to consider the work of Guaman Poma de Ayala to be instantly instrumental for Churata, "la biblia le llamo yo" (163). Churata came to appreciate the role of Nueva crónica as a literary rather than historical text, and the role of Poma for his aesthetic and linguistic hybridizations that challenged the textual authority of a monolingual historic text, "obliga al español a una hibridación pintoresca, su simplicidad resulta inquietante y sorpresiva. Guaman es un temperamento con sensibilidad estética" (163). Churata was intrigued with Poma in his ability to not only form an aesthetic sensibility to his writing, but in his ability to “indianize” Spanish language and European mythology.

The first strategy of hybridization which captured Churata's critical eye was Poma's hybridization of the two distinct mythologies, "Inmaculada Virgen y Madre de Dios, y de los creyentes; y, como a real y verdadera Wiñay Cusiatha y Kota-khanaway y Titikaka de los Arusayas del Inti-llampu en su Apupu-Wakawy del Tawantinsuyu. A la cual Divina Reyna del tiempo y de la eternidad, sea el sin fin: ¡Ilillu! ¡Llally! ¡Iyau!” (159). This comparison between the European Virgin mother and the Andean mythological figure, Pachamama, "Reyna del tiempo de la eternidad," forms a hybridity of belief regarding human origins. More than attempting to infuse Spanish with deep traces of Andean culture, Poma represents the Virgin Mother and the Christian religion mestizo cultural products. This is a complete inversion from Garcilaso's strategy of Christian discourse to help humanize Andean cultural practices. By recasting the Virgin Mother through an Andean perspective, colonial cultural impositions were more 
easily integrated into the Andean reality. Churata comments on the success of such a cultural practice:

Tantas catequistas y jesuitas...rivalizaron en el empleo de las lenguas indígenas para las finalidades de las impacientes levas parroquiales, e hicieron verdaderas filigranas en prez de la Virgen Madre, indianizándola...impusieran el conocimiento del idioma indígena y...concedían la importancia del idioma como medio único de llegar a la mentalidad del catecúmeno y cuánta elasticidad para adoctrinarlo. (159)

Through the implementation of Christianity through Quechua and a recasting of Christian figures as Andean ones, Andean and European practices of ritual and worship found spaces of encounter and overlap where characterizations of natives as savages began to subside, "venerar en sus grandes mitos los símbolos del cristianismo" (160). This cultural hybridity is an important one to consider as it does not imply a cultural harmony: "acá no se manifiesta la fusión de dos sangres, pero es inevitable constatar la fusión de dos espíritus en un plano de categorías mentales" (162). Churata reminds the reader that these distinct worldviews do not wish to find a harmonic resolution, what this hybridization seeks is a function of language which enables cultural survival.

Another possibility within the hybrid option is the aesthetic function of phonetic spelling within Poma's writing. Guaman Poma combines phonetic transcriptions of Spanish with elements of Quechua toward the goal of instilling a new Andean aesthetic which can revive a semblance of cultural autonomy. Reflective of the role that vulgar Latin had in instilling more power of expression to dominated classes, the writing of Guaman Poma was able to penetrate Eurocentric representations and invert them into a new heterogeneous product which spoke toward Andean sensibilities, "Guaman encasqueta al español la fonética de su lengua, cárgale su acento grave, y emplea el 
kheswa a guisa de excrilogía latina” (164). Rather than directly confronting, rejecting, and reversing all Eurocentric conceptions of the indio, Poma instead chose to express the condition of the indio by writing in a language that lends to orality, “... y esta gente no sabía hazer rropa bestianse hojas de arboles y estera texido de paxa no sauia hazer casas, ueuian en cuevas y peñascos" (163). The function of this orality becomes immediately apparent to the reader. Churata's use of bold type indicates Poma's fluxuation between Spanish (bold type) and Quechumara (normal type) as seen in the citation on the previous page. Yet this specific citation is not obviously Spanish, only a vocal reading allows the use of Spanish to come through in words such as "ueuian" and "sauia." A vocalized reading of this citation gives us a rendering of what Poma's Spanish sounded like. In short, we begin to see traces of Andean aesthetic becoming a component of the major language. Beyond turning Spanish into an oral language, Poma is able to inject his own untranslated indigenous language, as well as form a hybrid meeting place between the distinct worldviews.

Through allowing a textual space for the introduction of the Quechua language and syntax, Poma had set forth the creation of the new language of resistance that infused itself into the national consciousness, "hibridación idiomática que sería lo más vivaz de la resistencia india frente al dominio hispano" (165) which Churata would carry out throughout the entirety of his writing. Hybrid language acting as a form of resistance to Spanish cultural domination constitutes the onset of the possibility of an American Literature; a hybrid literature which comes about through a process of conflict, evolution, and resolution. A lack of these characteristics translate to the formation of a national consciousness which remains ignorant to its own particularities, and which never 
challenge its origins. It is through a constant challenge to conceptions of origin and history from which the Andean American identity and literature can spring, "Guaman permite descubrir algún atisbo germinal como síntoma o posibilidad de una Literatura Americana" (165). Churata, reflecting early signs of the new historical novel movement which blossomed within Latin America in the late 1970s, saw the potential of a historical text to be inverted into a literary text through its reliance on aesthetics, cultural hybridization and the ideological construction of meaning within historical texts.

Beyond allowing the space for a hybrid language, identity, and literature, the writing of Guaman Poma revealed to Churata a deep underlying truth to the idea of the Andean American reality and the place of expression for subaltern subjects within it, "si América es una realidad genéticamente mestiza, la literatura americana debe ser idiomáticamente híbrida" (165). The new hybrid American language, which Poma introduced, and was subsequently altered by Churata to meet his own aesthetic, allowed for Andean expression to become a characteristic of the new American Literature. More than a textual hybrid which allows for heteroglossic language, the hybrid American language makes the mestizo an indispensable character, and his language an indispensable aesthetic. By attaching native aesthetic and mythology onto a Eurocentric text, the resulting hybrid product can be called an aspect of a heterogeneous, even American, literature as it could only come about through the resolution to the cultural conflict between European and Andean realities.

The role of the modern metropolitan capital in a decolonial context offers many new forms of cultural expression and conflict between dominant and dominated cultures. Resolutions to these conflicts often develop as processes of acculturation where native 
cultural practices and institutions begin to waver under the pressure of oncoming modernity and colonial power structures. Through this context, the idea of American Literature becomes more closely attached to Spain than the cultures it claimed to represent. Churata explores this dichonomy when he notes, "afirmamos la vigencia de una Literatura Americana no por sus raíces americanas sino por el cosmopolitismo oceánico que rompe todo pudor y candidez a la expresión estética...pero este americanismo no es americano" (167). Churata recognizes the irony of forging an American Literature that can never fully escape from its dominating origins to be its own form of expression.

What Churata's writing seeks to resolve is how a renewed sense of Andean Literature and identity can develop while the nation is economically and culturally attached to Spain and whose cultural products are rendered inorganic. Churata poses the question as to how can American Literature be American when derived from Spain, Spanish, and is external to those it attempts to represent. One answer may be that American Literature is defined by its duality of identity, an acceptance of fictionalized origins, and the finding resolution to cultural conflict through hybrid forms of expression. The possibility of American identity is one that can only come about through a focus on the role that national literature plays in forming our conceptions of national origins, history, identity, and traditions.

The role of national literature and its attachment to national identity lies at the heart of Churata's excavation into the subjugation of Andean expression under imposed European forms, a process of excavation which he carries out throughout El pez de oro. Churata argues that the hybrid aesthetic, framed by Europe yet occupied by the Andes, 
needs to be expressed through the indio, "la verdadera capacidad estética de la América está en la sangre del indio y, por tanto, la forma de hacer estética americana es hacer de América un mundo indio" (167). The indio maintains the possibility of extending his expression into the national consciousness given a form of expression which prioritizes his positioning as the main subject and actor within Churata's idea of American Literature.

After analyzing the styles of textual hybridization used by Inca Garcilaso and Guaman Poma, Churata begins to present his own working conception of what this American language may look like. Moving beyond critical theory and essay writing, narration of "Homilía" begins to move into a performative, oral, and multilingual prose that examines the constitution of Andean identity by returning to the origins of Andean mythology and the role of Khori-Challwa. More than a figure of Andean mythology, Khori-Challwa acts as a symbol for a new Andean world and the New Andean American subject. Churata concludes the theoretical portion of "Homilía" by asking, in the form of dialogue, if and how this American subject can emerge, “¿Hay, en ultimo análisis, un hombre americano?" (205). With the arrival of this question, Churata then pushes into his fictional prose section, "Radiografías del Cancer," and presents the possibility as the Khori-Challwa, a symbol present within all Andeans:

¡Naya! ¡Naya! ¡Naya! ¡Naya! ¡Naya! ¡Naya! ¡Naya! ¡Naya! ¡Naya! ¡Naya! Khori-Challwa: ¿Eres el Chullpa-Tullu a que mis huesos se saben enfeudados? Relámpago de mi carne, tú la iluminas en Él, y Él eres con todos los caudales del Universo Bien sé que en ti sólo hay un hombrecito del Titikaka...Sé bien que EL PEZ eres; aquél que en mi sangre latía cuando esperaba, y esperaba, en los barros del álveo, y ni el Sol era Lupi, ni se había animado dios alguno en las profundidades del átomo. Eres mi existente porque eres mi habitante. Y, cuando amo, y beso, y lloro, es más que manera de ser en Ti, sentimiento espasmo de mi hueso. 
¡Tú eres naya! ¡Tú eres naya! ¡Tú eres naya! ¡Tú eres naya! ¡Tú eres naya! (205) One of the first clear examples of Churata's fictional prose voice, the citation is wrapped up in references to Andean mythology, infusions of Quechumara, and a general sense of his more performative orality that guides his fictional narration. "Naya," Churata's own neologism referring to the possessive "I," is repeated and may be a cry seeking to resolve the question as to whether or not the American subject exists. Our narrator cries out saying that he is this new subject, except he cannot be understood. He then goes on to address Khori-Challwa directly to ask him if he is the remanence of the living dead, the living memory of Andean ancestry and tradition. The narrator attempts to fuse a bond between the skeletons of the ancestors with his living flesh as together they form the idea of the past and present coming together to form a new collective subject, "¡Tú eres naya!” or "you are me." They cry out their new identity in unison as the forge on into the Andean mythological underworld.

"Homilía" is an extensive retablo that offers a reader a broad cultural context under which Gamaliel Churata conceptualized and executed the framework of an Andean aesthetic which he hoped would be carried out in the fields of cultural and political expression. Concerned with a critical analysis of the formation of the Andean and American identity through colonialism up to the period of expanding modernity, "Homilía" remains an important and expansive essay on colonial identity and postcolonial cultural agency. "Homilia" can serve as a critical essay or primary source for studies regarding Latin American identity, the formation of national literature, consciousness, and can help unravel the cultural conflicts regarding ideas of colonialism, and steps towards decolonization in a post-independence context. 
The title of this chapter posed the question as to whether or not there exists a possibility for the existence of a true American Literature within a Eurocentric hegemonic society. Within "Homilía," Gamaliel Churata makes it evident that there does exist this possibility when developed through a concentration of Andean aesthetics toward a hybrid language where Spanish meaning is disrupted, colonial authority decentered, and Andean agency can be restored, “español tendrá que hibridarse rindiendo parias a Guaman Poma, o romperemos los atajamientos de Garcilaso, volviendo al Aymara y kheswa...Y ya podremos hablar de Literatura Americana" (185). What historic Andean figures such as Inca Garcilaso and Guaman Poma allow for are reconsiderations of the American identity brought about through challenges and inversions to collective colonial textual authority over historical representations of Andean societies.

The textual and narrative mutations that define the writing of Garcilaso and Poma set the stage for the creation of a truly American cultural text. In his article, "El Inca Garcilaso, 'Clásico de América', en las obras de José de la Riva-Agüero y Marcelino Menéndez Pelayo," Enrique Cortez indicates how colonial figures such as Garcilaso and Poma opened a space for American cultural production, "lo que actualmente llamamos literatura colonial se integra por primera vez en una narrativa de la historia literaria del Perú, no sólo como un antecedente de lo republicano... sino como un espacio de originalidad americana" (82). ${ }^{13}$ Within this new American space came other possibilities for producing cultural products influenced by both processes of modernity as well as

\footnotetext{
${ }^{13}$ In this search for an original expression of the American identity, it would be useful to connect Churata's ideas with those of José de la Riva-Agüero who argued for "americanismo histórico," which seeks for reflections of originality within pre-Columbian Andean cultures as a means of challenging conceptions that all Peruvian Literature is necessarily an imitation of Spanish Literature and classic literary figures. See Carácter de la literatura del Perú independiente by Riva-Agüero for more information on this topic.
} 
reflections of tradition toward an empowerment of renewed cultural production. One of the major cultural productions that Churata further developed within his own writing was the possibility of an American language which, like Garcilaso and Poma, attempts to reach into the past while forging a new sense of future autonomy. 


\section{Chapter 2}

\section{Quechumara and the Role of Minor Literature in "Morir de América"}

In his search for the possibility of an American Literature, Gamaliel Churata focuses on two key cultural components: language and history. For Churata, these two components are inherently linked when attempting to revive a sense of lost Andean origins and to be able to forge a modern Andean future. While the resurrection of a historical period aspires toward an ultimately impossible utopian ideal, the resurrection of language constitutes a valid renewed sense of tradition. Churata envisioned that through the revival of subordinated language a true verifiable semblance of the past can begin to take shape. Yet this resurrected sense of past and tradition is not concerned with truth, Churata was intrigued in an aesthetic revival as history had already been erased and, literally, written over. Rather than a representation, Churata was interested in expressing a specific Andean aesthetic developed between the tensions of the distinct languages toward the creation of a new heterogeneous language. By infusing traces of the indigenous language into the dominant one, the dominated culture can begin a slow process for the recuperation of cultural and territorial autonomy. His new hybrid language constitutes a new modern language that is equally tied to tradition and experience. The cultivation of a modern heterogeneous American culture that draws from the modern and the traditional constitutes the base of Churata's aesthetic project.

In Gamaliel Churata's theory on the formation of the American identity, Eurocentric narratives prevent the Andean subject from being an autonomous agent within their own culture, traditions, and origin. As a means of lending a renewed sense of autonomy to the new Andean subject who came about as a product of heterogeneous 
tensions throughout the period of modernity in the Andes, Churata sought to express the Andean American subject as a hybrid identity whose societal institutions and practices are hybrid products in a constant state of reorganization, "la sociedad funciona como un cuerpo que pasa por etapas vitales, sufre enfermedades que requieren diagnósticos, curas, extirpaciones, etc., una noción que se encuentra también en Churata” (Moraña 60). The idea of society as a corporal entity is pertinent when considering the role of the Andean society within the colonial context. The Andean subject has seemingly become a nomad within his cultural space; the institutional and cultural consequences of colonialism have separated the Andean subject from Andean places. Our narrator, a symbol for this divided subject, wanders the shores of Lake Titicaca in search of his lost origin. He seeks a path to reclaim his cultural space through searching for traces of origin and truth within the language of his culture. Through mythological musings and language that borders on a performative structure, our narrator probes the possibility of the new Andean American language.

The new Andean subject, a nomadic migrant subject is search of his restored origin, forms the base of the Andean American Literature where myth and truth, fiction and history, and origin and regeneration blend into a renewed form of cultural expression led by Churata's experimental, and political, language. The new Andean subject acts within the desire for a new Andean Literature where language, expression, and style compose the basis for this dialogic style which necessarily lends itself to the avantgarde genre due to its experimentations of form, style, language, composition, syntax, and performative utterances, to only name a few of its distinct characteristics. Beyond its avantgarde form, Churata's new language acts towards a political function of 
decentralizing and de-standardizing the dominant language. These territorial wanderings, political and cultural upheavals, and Churata's theory that the new American language will need to go through many generational stages before becoming a reality appeal toward the classification of $E l \mathrm{pez}$ de oro as a strain of a minor literature.

Focused on the last expansive retablo, "Morir de América," this section is interested in exploring Quechumara on a more analytical level by presenting it as a branch of a minor literature. This closing retablo lends itself well to an analysis of Quechumara as a minor literature given its practical counterbalances to the theoretical retablo "Homilía a Khori-Challwa" due to its exploration of Andean references, hybridization, and search for Andean identity through textuality which culminates in the symbolic battle between the future Inca Khori-Challwa and the monster Wawaku in the depths of Lake Titicaca (El pez de oro 791).

The longest of all the retablos, "Morir de América" continues the narrator's search for voice within a language that is both traditional and modern, regional and foreign, as he roams the shores of Lake Titicaca. In search of this language, the narrator lends aesthetic interpretations of the nature around him through a use of references to Andean mythology, animals, and a strong reliance on intertextuality and dialogue. The language of this search is Quechumara, where traces of baroque Spanish begin to dissipate behind the flood of Andean orality, birdsongs, Andean aesthetics, and performative utterances. What these physical wanderings and aesthetic language make visible is an interpretation of our narrator's search for identity as a process of movement where the subject has been reterritorialized from his cultural space which has now become alien to him. He seeks to revive his lost land of origin through an aesthetic mix of 
Spanish with Quechumara vernacular toward an expression of the land of Andean origins. From this search engaged with the restitution of a lost cultural landscape, the categorization of El pez de oro as a minor literature become clear.

While the categorization of El pez de oro as a strain of minor literature occupies the background for this chapter, and will be explained shortly, this argument must be situated within the function of the aesthetic language which Churata cultivates, and which has been credited as the most probable reason for his exclusion from the Latin American canon. Helena Usandizaga explains the conflict revolving around his style and production:

En torno a este reto hay actualmente un consenso, el de la necesidad de estudiar más a fondo esta obra - que no es una novela, ni un ensayo, ni un libro de poemas, y es todo esto a la vez — para incorporarla a la tradición. Hay también una disensión: en los últimos años, parece que la discusión se está polarizando en torno a la idea de si se trata de una obra conectada con la cultura andina, o bien si su peculiar estructura y punto de vista los explican más bien las referencias vanguardistas. (177)

The lack of theorists able to situate Churata within identifiable categories such as indigenista or vanguardista led to a fracture in its categorization that resulted in his being pushed aside and marginalized within Latin American literature. Before investigating how the classification of $E l$ pez de oro as a minor literature can help rationalize its peripheral categorization within Latin American Literature, a proper definition of Quechumara should be explained.

Quechumara is a term coined by Churatian scholar Mauro Mamani Macedo first within his dissertation work before culminating in his critical work, Quechumara: Proyecto estético-ideológico de Gamaliel Churata published in 2012; the same year Churata began to explode more into academic circles due to the publication of the 
Cátedra edition of El pez de oro. While presented as a language, Quechumara should be more accurately conceived of as an aesthetic decolonial practice, function, or option carried out within the major language of Spanish. Even though Quechumara refers more towards Churata's use of style, structure, aesthetic, voice, and ideological meaning carried out in his language, it is also a cultural project that ties territorial writing to the land itself. Mamani Macedo presents Quechumara as a political project that draws on geography and culture, "Churata...se ha permitido fundir en sus discursos de representación un "repertorio" cultural que no solo tiene que ver con dos naciones, Perú y Bolivia, sino con dos culturas, Quechua y Aymara" (30-31). This concept of Quechumara as investigating dualities of culture and nation through conflicts of language and representation make it a textual practice that attempts to decouple cultural tensions and create a new aesthetic forged through conflict. Mamani Macedo discusses how Churata's language engages in an unending process of affirming one's own culture while simultaneously being able of assimilating towards aspects of the dominant culture:

En la obra de Gamaliel Churata emerge un proyecto estético-ideológico en el que conviven tensionalmente lo andino y lo occidental completando una compleja refractación de la diversidad cultural del universo andino. El discurso tensional de Gamaliel Churata tendría como estrategia la afirmación de lo propio y luego la assimilación de lo ajeno, esto como resultado de una feliz coincidencia entre el sujeto de la enunciación y el sujeto civil que he vivido la cultura quechumara, por la que plantea la reivindicación del mundo andino. (16)

The textual practice of creating cultural and linguistic tensions toward a resolution which allows the revival of the Andean world under modern terms is what I mean when referring to Quechumara as a literary practice. As a literary practice, Quechumara and the writing of Gamaliel Churata open themselves up to categorization as a minor literature. El pez de oro, I believe, can be situated well within the category of a minor literature as it 
seeks to use language variation in order to resolve a series of cultural tensions which have culminated in the Andean identity being cast as a minority within their own territory and language, essentially making the Andean identity one that exists on the periphery of the Peruvian national consciousness.

The definition of a minor literature is not one that designates a separate class of literature produced within a minority language, rather it is the variations that a minor culture or language introduces into a major one. Gilles Deleuze and Felix Guattari define minor literature as such in Kafka: Toward a Minor Literature, "minor literature doesn't come from a minor language; it is rather that which a minority constructs within a major language" (16). Deleuze and Guattari explain that minor literature is a practice interested in using language as an object of study toward exploring the homogenizing power of language to erase cultural or territorial difference. Deleuze and Guattari were interested in how language variation between a dominant and dominated culture/language can lead to a process of continuous variation (Thousand Plateaus 102). If we apply Spanish and Quechua and Aymara to this context, Quechumara fits well within this definition as it is a language practice which constructs itself within the dominant language of Spanish and attempts to destabilize the homogenizing effects of language imperialism. The narrator searches for a way to express his new hybrid world through a language that he was born into, yet remains distant from. In such, he must foster his own heterogeneous language.

As I mentioned earlier, Quechumara is a textual practice rather than a proper language in itself. Quechumara exists as resistance against Spanish homogeneity, making it a perfect candidate for classification as minor literature, "Minor languages do not exist in themselves: they exist only in relation to a major language" (Thousand Plateaus 105). 
From this definition, minor literature is the study of the role of an oppressed majority culture within their own territory yet who have become deterritorialized due to colonialism and the imposition of colonial culture. As a language constructed within a major one toward the end of reconstituting the role of native culture within a colonial context, destabilizing the authority of the major language, and acting as a language which does not exist in singularity, Quechumara aligns itself with the three characteristics of minor literature: first, "language which is affected with a high coefficient of deterritorialization," second, "everything in it is political," and third, "everything takes on a collective value" (Kafka 16-17). These three characteristics will be examined individually to show how El pez de oro can be categorized as a minor literature when led by Quechumara as a textual practice toward the goal of igniting the new Andean aesthetic.

As minor literature focuses on the agency of an oppressed majority racial or cultural group within a major colonial language and its literature, one of its major goals is decoupling the unity of language between a text and its subject of representation. Deleuze and Guattari present two different approaches to destabilizing the territorialization of the dominant language over the dominated: the use of vernacular and the use of bilingualism. These two approaches play an important role in the formulation of a minor literature practice, “'major' and 'minor' do not qualify two different languages but rather two usages or functions of language" (Thousand Plateaus 104). The use of bilingualism can constitute a function of language when under a colonial context. For example, while Czech and German are not the same language, Gilles Deleuze considers Czech as a minor language in relation to the dominance of German. I will apply minor literature in this 
same context of Quechumara and Spanish where Churata's injections of the indigenous languages "send the major language racing" (Thousand Plateaus 105) and act as a challenge to the idea of national literature where the role of Andean culture cannot be denied when made an inherent aspect of the national consciousness. The idea of nation, national literature, and, above all, territory construct the first characteristic of a minor literature.

Deleuze and Guattari reason that the first characteristic of a minor literature is that it must contain a language affected through deterritorialization. As I have discussed through the period of colonialism up through the period of indigenism and even extending into the present, the Andean subject and his culture has mercilessly been decoupled from the place of its origin, the Andean region and Lake Titicaca. Churata approaches this deterritorialization by presenting the impossibility for the Andean subject to be able to express their reality in Spanish. Yet at the same time, Churata understood the impossibility of not writing in Spanish if he wished to garner a wide audience. In other words, the representation of the oppressed majority group within their own territory must take place within a language alien to their territory.

Through the deterritorialization of the language from the land and culture which it sprang and forcing the Andean subject to write in Spanish, Andean authors become disentangled to their native language, "minor authors are foreigners in their own tongue" (Thousand Plateaus 105). What Deleuze and Guattari attempt to argue is that a complete use of indigenous languages would register as alien within the canon of Peruvian national literature. Rather it is through a hybridization of the minor language of the oppressed cultural majority with the major colonial language that can re-orient the native subject 
within his cultural space. While the dominance of Spanish and its ability to delink the Andean subject from his culture and space constitutes the base of deterritorialization, it is through bilingual or vernacular variations within the major language that the oppressed subject can reclaim his language, culture, and, by proxy, his territory.

This acknowledgment of deterritorialization, and the use of Quechumara as a process of reterritorialization is a constant within Churata who attempts to blur imposed homogeneous cultural boundaries and unite the Andean diaspora through a restructuring of the Andean spirit ignited within Quechumara. Quechumara allowed Churata to bring together aspects of Quechua, Aymara, Baroque Spanish, and even Latin to form a hybrid language that pushes Spanish to its limits while allowing the Andean subject to inject his own culture. This language blossoms within El pez de oro whose main function is that of lending a specific Andean aesthetic, or lyrical tone, when describing mythological worlds, subjects, and Andean nature itself. The retablo begins:

Una gota. Otra después. Y van cuatro, cinco, seis. Cuántas ya...No muchas; todavía se las puede contar...

${ }_{-}$NNa phara hamunki!... ${ }^{14}$

Atruenan los mugidos del viento; hay en la espuma atoros bermellón; la Ururi suelta chaskosas ${ }^{15}$ viboritas de fuego; escoriaciones del llachu ${ }^{16}$ lentejuelean revoltijos de oro en ala de la ola; acollaran pompas de jabón las esmeraldas del totoral... Y, ya, en un chukchu ${ }^{17}$ de caireles, fuga, cabrilleante hemorragia de sutuwailas ${ }^{18}$.

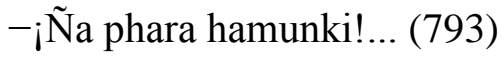

Throughout this citation, Quechumara as a minor language and $E l$ pez de oro as minor literature take on multiple possibilities. Throughout "Morir de América," Churata uses

\footnotetext{
${ }^{14}$ Guión: Kh. Viene la lluvia.

${ }^{15}$ Guión: Hib. Lo enmarañado. La chaskosa se llama a Venus por sus vivos centellos.

${ }^{16}$ Guión: Kh. Ay. Helechos lacustres.

17 Guión: Ay. Temblor desde lo interno del tuétano.

${ }^{18}$ Guión: Ay. Lagartijas
} 
the sound of rain in multiple prose languages, "Una gota. Otra después. Y van cuatro, cinco, seis" for Spanish, and "ña phara hamunki" in Quechua to form a sense of rhythm to the text where the sound and image of rain is a constant. By allowing for the same aesthetic image of falling rain in distinct languages, the homogenized centrality of Spanish begins to slip under the influence of the minor language. The more the major language begins to acquire traces of the minor language and the culture of the land, the more Spanish can be deterritorialized from its imperial post, and the Andean subject can be reterritorialized.

The shift towards a heterogeneous language involves more than infusions of Quechua into Spanish and also involves the infusions of Aymara and Quechua into one another. The interjections of "chaskosa, chukchu, llachu" and countless other uses of minor language play a critical role within Churata's aesthetic project. As I will develop throughout the remainder of this thesis, the role of intertextuality within El pez de oro often engages Andean mythological figures, biblical subjects, occidental philosophers and colonial texts themselves, such as El diario de a bordo towards the goal of fostering communication between the distinct cultures while revealing the conflicts inherent within their communication. In his construction of an aesthetic which seeks to enable cultural agency without idealizing a utopian past or rejecting the culturally significant contributions of Europe and modernity, Churata proposes that American Literature can only come about through variations to the dominant and dominated cultures, and the political frameworks which define them.

Churatian scholar Riccardo Badini in his article, "Los inéditos de Gamaliel Churata" situates the function of variations within the two languages as steps towards the 
new Aesthetic and the role of the Andean subject within it, "rechazando por romántica la recuperación arqueológica de las lenguas indígenas, propone, basándose en la observación de la realidad popular puneña, el hibridismo lingüístico como instrumento para expresar una América del Sur con ego" (210). More than reinvigorating the role of the Andean subject within a major language, these infusions of the minor language add to the major language by allowing words which escape cultural translation. By using indigenous words to represent aspects of the Andean mythos or worldview that remain untranslatable, the minor language is lent a space for expression.

The idea of preserving or adapting indigenous languages into the modern social context was a main concern for Churata. In "Homilía a Khori-Challwa" Churata asks, “El indio se mantiene leal al idioma lácteo, persigue elevarlo a la escritura, servirse de él para sus menesteres superiores o siquiera íntimos? No. El indio busca superar al mono antropoide en que acabó colándose a las heráldicas del mestizo" (162). Within this proposal for language variation is the possibility of a new language and, consequently, a new literature; an American Literature. What these infusions and variations invite is the introduction of "continuous variation" within a major language that destabilizes the major language and enacts "the major language's entering into a becoming-minoritarian of all its dimensions and elements" (Thousand Plateaus 106). The function of Churata's language toward destabilizing Spanish as being a language capable of reflecting Andean reality is highlighted by the infusion of Quechumara towards the creation of an untranslatable aesthetic. This decoupling of Spanish from both the Andean subject and their aesthetic sets a foundation for the reterritorialization of Tawantinsuyu under a new American conception. 
A second aspect of deterritorialization goes beyond allowing variations within the major language and involves the mixing of incompatible ideologies where Andean and European historical, political, and cultural discourses create a tension whose product is a diverse, yet complete, representation of the modern Andean aesthetic and subject. The project of Quechumara presents a hybrid culture that seeks to affirm the Andean through a process of integrating external cultures that have no attachment to the Andean ayllu; ${ }^{19}$ or community. The disentanglement of Quechua and Aymara from the land and allowing for an assimilation of European modernities into an Andean cultural space enables cultural deterritorialization. A process of reterritorialization must enact a process of decoupling the oppressive language from the land and enable a cultural resurrection, a process that is carried out within El pez de oro as our narrator-protagonist journeys throughout the altiplano in search of his buried ancestors and ayllu:

Que todos llevamos vivos a los muertos, que lo muerto vive. Pensar que el Inka también lo sabía fue entonces para mí causa de hondas perplejidades; y que con esa majestad de ley, de que tan bien hacía alarde, determinase que los muertos debían sometérsele, por lo que les marcó ayllu, y les impuso jefe, convertía mi asombro en estolidez... ¿Hay, por ventura, mensurable distancia a la certitud del runa-hakhe ${ }^{20}$ de que el muerto ha sed, hambre, frío? Apreciadas ambas actitudes se ve que nada mensurable las separa; y que si aquélla siente vivo su Amoroso Palomo, y en el ardido pecho sus espantables necesidades de ser, de eternidad, de vida...; el kuiku no sólo conserva vivos sus rediles, sí que sus rediles balan y triscan más allá de las fronteras oscuras. (560)

Concentrated on the idea of the dead persisting into the living, the past into the present, and the role of colonization which severed the kuiki from his ayllu, Churata's language is

\footnotetext{
${ }^{19}$ See Quechumara by Mauro Mamani Macedo for a detailed analysis on the role of the ayllu within Andean cultural production and its relevance within el pez de oro.

${ }^{20}$ While not present together in the Guión lexigráfico, "Runa- "is s prefix for "man" and "hakhe" also connotes the idea of "man" or a man of the people. In short, the Runa-hakhe is an important cultural component for Churata and has been investigated as the construction of the future Andean identity enabled by a return to the collective Andean spirit (Mamani 78; Usandizaga 57). See "Introducción" to Mamani Macedo's Quechumara for a more detailed analysis of the role of the Runa-hakhe.
} 
able to infuse traces of the dominated language into the dominant one. Beyond a language which leaves a spotted trail of Quechua and Aymara that can lead the reader back to the altiplano and bloom into a new ayllu, Churata points out the ability of Spanish and its impositions to define the indio and delineate the reach of his culture when he refers to their imaginary borders in terms of an animal enclosure whose limits are dark and undefined. Churata's admission that borders are an imagined idea that can shift along with the migration of a community situates the possibility of a reterritorialization of Andean culture to the altiplano when led by a new language, aesthetic, and subject. Armed with this new cultural tool, the Andean subject becomes capable of producing new authentic cultural products that may best be called transmodern in that they carry aspects of traditional as well as more modern culture. Antonio Cornejo Polar has argued that the resurgence of these culture producing Andean subjects held greatest significance in cities of developing intellectualism who were "intrinsically bound to the problem of modernity" (114).

As discussed earlier in this thesis, Puno was heavily engaged with the problem of modernity during the early twentieth century and the centrality of Lake Titicaca within Andean mythology. In the process of reterritorialization within El pez de oro, the reader must keep Lake Titicaca and the surrounding cities of Puno and La Paz in mind as they constitute the cultural attachment between Andean culture and space. Puno was at one point considered "la region más india del Perú" (Bourricaud 67) in part due to its bustling modernity that had yet to erode the presence of a distinct Andean culture and where modernity presented peripheral intellectuals the possibility of creating distinct textual practices and focuses that illuminated the Andean spirit. 
The second characteristic of minor literature is that it must use the political as a central focus of its content and sociocultural function without isolating the political context as a background serving the larger narrative. I return to José María Arguedas, and his novel Los ríos profundos, as a fitting example of a work which uses political context as a background to frame an individual narrative of Ernesto's struggle for recovery of identity and mestizo belonging in a politically divided community. Within a minor literature, there is no one individual concern that serves as the driving thematic force framed by a background of socio-political context. Rather, minor literature invests in a kaleidoscopic framework where the political, cultural, social, economic, historical, and the literary share a magnified multi-dimensional space. El pez de oro does not narrate a young couple fleeing political violence, or a prominent social figure wrestling with his demons framed by a background of social turmoil. El pez de oro presents a narrative which favors a language that reflects the changing Andean reality without binding the reader to one individual context.

One of the intriguing manners by which Churata distances himself from a concentration on individual contexts and allows a more expansive political one is through a concentration on symbolic language and the symbolic relationships shared between mythological and physical realities, "Los huesos de chullpar hablan; y, cómo hablan, aman; y odian como aman; y si odian matan. ¡Guay del felón descreído! Su alma y su cuerpo serán atenazados por el muerto. Ellos son ajenos a la vida; ni problema alguno que conturbe a los hijos puede ser indiferente a los padres muertos..." (561). Churata evokes a symbolic living past which is enabled by an idea of a living dead where the bones of Andean ancestors, Los Chullpas, are able to influence the future for good or bad, "odian 
como aman; y si odian matan.” The symbolism Los Chullpas as active Andean agents is one caught between ideas of life and death, and the symbolic role of ajayu, or soul, and ayllu, or community. There is no individual subject or theme which drives this narrative, allowing the political symbolism of cultural erasure and resurrection to shine through. This political cultural conflict is displayed through the generational relationship where the current generation is tasked with carrying the culture of their dead ancestors into the future and announcing that they are still alive, only dormant.

While bound within the old Andean world, the new Andean subject, KhoriChallwa, wishes to break free and create his own new Andean world, “...cuando me encarcelaron muchas fogatas atizadas en los kollos de la pampa concitaron a los encargados de la protección del kuiku y de su mundo; y los Mallkis, puntuales, abrieron mis cejas" (561). The presence of a direct object, "me," does not distract from the idea of a political over individual context as Khori-Challwa serves a purely symbolic role that can illuminate the generational conflict between father and son. One is embedded in tradition, while another seeks a new beginning. To return to an earlier citation of "Tú eres Naya," or "you are me," Khori-Challwa is a collective symbol for the new Andean subject. Through a "purification of the conflict that opposes father and son" (Kafka 17) the symbolic political context of liberation comes about. While Khori-Challwa wishes to usher in a new Andean world while still protecting traditions of the old order, he must confront the ghosts of the old world and find resolution in order to break free and become an active culture-producing agent. In the same way Andean subjects wish dispel the authority of colonialism in order to reclaim a sense of agency over their future and allow their own cultural production. 
The third and final characteristic of a minor literature is that "everything takes on a collective value" (Kafka 17). Related to the second characteristic, collective value carries meaning in a minor literature as minor literature lacks the canonical voices which sustain major literatures and must construct itself through many individual enunciations coming together as a whole. Deleuze and Guattari describe this collective value as one where "there are no possibilities for an individuated enunciation that would belong to this or that 'master' and that could be separated from a collective enunciation" (Kafka 17). Collectivity plays a large role within El pez de oro where the role of Los Chullpas and the ayllu are paramount to sustained cultural life, not to mention the importance of community and collectivity when considering the decolonial option and its focus on the development of community toward future global cultures.

Throughout El pez de oro, Gamaliel Churata evokes collective value through a reliance on mythology, the oral tradition, and a concentration on the conflict between orality and textuality. I believe the Andean oral tradition applies neatly to the idea of collective enunciation of sound as defined by Deleuze and Guattari as Churata is drawing on mythical figures and the sounds of nature as a driving aesthetic force:

Language compensates for deterritorialization by a reterritorialization in sense. Ceasing to be the organ of one of the senses, it becomes an instrument of sense. And it is sense, as a correct sense, that presides over the designation of sounds and, as figurative sense, over the affectation of images and metaphors. Thus there is not only a spiritual reterritorialization of sense, but also a physical one. (Kafka 20)

The reliance on sounds of songbirds persists in the Andean oral tradition and becomes a key concentration for Churata who encapsulates this enunciated orality around two keys 
narrative elements: the role of textualizing sounds of the Andean world and dramatic performance.

While beginning to examine the role of the oral tradition within El pez de oro and the restitution of the Andean ayllu, it is important to consider the main subjects within this tradition - Andean mythological subjects. Constructed throughout generations of the sustained oral tradition, representations of Pacha-Mama, Khori-Challwa, and KhoriPuma are an assemblage of many generational voices where the individual voice fades within the collective subject. Limited to these collective subjects, Andean mythology serves a collective symbolic function that extends from their origins into the present. The role of orality as a collective value within $E l$ pez de oro is one based in the sustained oral tradition in the Andean region and throughout Andean history where oral memory can find balance with written documents. Both orality and textuality are enabled by human agents and remain open to individual ideological and/or aesthetic alterations.

In the Andean oral tradition, myths and histories were recounted by individual historical memory in which each performance could highlight, erase, or alter certain narrative moments, structures or elements. In this tradition, the Andean storyteller became a corporal archive whose voice and performance were individual but whose function served a larger shared social narrative. The individual repertoire of memory left itself open to intentional and unintentional adaptations enacted by the performer, "oral repertoires are both stable and unstable. The apparent permanence of many of their imaginative productions is, it is generally now agreed, the result of memory and repetition acting as guarantors of continuity" (Fraser 138). The reliance on individual 
performances of memory inevitably served to enable "verbal mutations" (ibid) that the oral artist added or subtracted from each oral account.

Gamaliel Churata approaches the conflictive space of orality and textuality and the underlying tension for the cultural autonomy of Andean representation by relying on a use of onomatopoeia and blending languages into the same textual space we can see the onset of what Antonio Cornejo Polar calls "the breakdown of previously institutionalized linguistic and literary conventions" (115). Through breaking down these conventions and inserting traces of Andean convention, a revival of the Andean world develops through language geared toward the reterritorialization of Lake Titicaca and the restructuring of the Andean ayllu as a cultural institution.

One of Gamaliel Churata's principal conditions for allowing a reterritorialization of Andean spaces has been discussed as he engages in differing forms of Quechumara as a decolonial literary practice. Another principal tool of reterritorializing the Andean subject, enabling political symbolism, and toward the formation of collective value can be seen through a use of articulated sound within "Morir de América." Deleuze and Guattari explain the role of orality in decoupling language and meaning, "the sound of the word that traverses this new deterritorialization no longer belongs to a language of sense, even though it derives from it" (Kafka 21). Cornejo Polar sets forth how this disruption of linguistic meaning returned a sense of historical legitimacy to narrative forms outside of writing, "we are speaking here of versions that, in addition, are not expressed through written narration but rather in ritual dances or representations that somewhat abusively tend to be called "theatrical"' (32). Through the conditions of distancing the relationship between signifier and signified, and the unstable relationship 
between orality and textuality, writing becomes disentangled from a fixed meaning and finds itself performing rather than inferring meaning, "under these circumstances meaning is more bound up in the action — and what it symbolizes globally — than in language" (42). Within these theatrical performative oral texts, like El pez de oro, meaning is found beyond words and are able to occupy a heterogeneous space between conflictive worldviews and interpretations.

Earlier I argued that uses of Quechumara allow for processes of reterritorialization by reflected an Andean aesthetic within the dominant language which could better represent Andean form and meaning. Yet in "Morir de América," Churata moves beyond aesthetic interpretations and into pure articulated sound. Guided by the rhythm of falling rain, birds begin to come out and announce their presence:

Negro venablo de orificado remo rompe la ampolleta de su trino, hace impacto bajo el alero de la chuklla, ${ }^{21}$ métese al nido, una lombriz deja caer en el pico de su hambriento; y si el lakhatillo ${ }^{22}$ se retuerce segundos desaparece devorado por el chiuchi. $^{23}$

— ¡Piupiu-titit! ¡Piupiu-titit!

Se alza del nido el chaiña-guagua, ${ }^{24}$ sus bracitos agita, y torna a abrir el insaciable pico.

— ¡Tititit!... ¡Tirol!... ¡Tirolí!... ¡Tirol!... ¡Tirol!... (796)

Churata goes on to allow all of the birds to liberate their expression and speak for themselves as he lends their names:

Sanguijuela del pezón, el Ungido de pelo muru-muru, celaje que espumarajea tibia y aurialba leche.

Los corderuelos:

— ¡Bala! ¡Bala!

El miura casanova:

${ }^{21}$ Guión: Kh. -Ay. Choza.

${ }^{22}$ Guión: Ay. Dim. Hib. Gusano de sementera. Lakhos, gusanos en general. Lkhatillo.

${ }^{23}$ Guión: Kh. -Ay. La cría, aún sin plumas, del pajarito. Pollito.

${ }^{24}$ Guión: Kh. -Ay. Jilgueros. More closely, the addition of "-guagua" implies hijo. Therefore, "the offspring of the goldfinch" is a fitting translation. 
- ¡Mugí-1́! ¡Mugííi!

El Cherekheña de Orko-pata:

- ¡Piupiu-titit! ¡Piupiu-titit!

El "Coronela":

— ¡Guau! ¡Guau! ¡Guau!

La Kharrajuskha:

— ¡Co! ¡Co, co!... Cocorocóóóó... Coo... Co... ¿Jaa!...

En la todavía ruborosa paleta de la pampa, el ¡cocorocó! Del gallo indio es eso: ¡kharrajuskha! Hispano acribillando las postreras purpurinas de la tarde. (796)

The songs of the birds and their own enunciations blurs any sense of meaning, the sounds speak for themselves, "in order to liberate a living and expressive material that speaks for itself and has no need of being put into form" (Kafka 21). These sounds exist independently of meaning, sense, or value while maintaining elements of representation. Churata's lone living son, Amaratt Peralta, remembers fondly as his father would hover over his keyboard and sing out these birdsongs to himself, imitating the sounds of nature while feeding cheese to the rats huddled around his feet. ${ }^{25}$

The representation of birdsongs is interesting in how if reflects a performative function of language that can work across different groups and languages. While aware that these are imitations of sound, they are undoubtedly different enunciations than would have been represented if written in Spanish. In other words, these onomatopoeias are a form of vernacular specific to the Andean region which can be seen throughout various versions of Andean huaynos and poetry. This is not the specific bilingual use of Quechumara where meaning is lost in translation, it is more a reflection of culture and territory.

\footnotetext{
${ }^{25}$ Amaratt Peralta was present at the Churata conference at the University of Pittsburgh in 2016 and gave a special guest lecture where he detailed many biographical anecdotes of his father, his reputation, the remaining lost manuscripts, as well as Churata's writing process.
} 
The manners by which Churata uses enunciations of sound to elicit a specific collective Andean interpretation of nature engages process of reterritorialization. It is a function of language which introduces variation into the representation of the natural or mythological world and allowed minor literature to be "thought of as seeds, crystals of becoming whose value is to trigger uncontrollable movements and deterritorializations" (Thousand Plateaus 106). By allowing an oppressed cultural group to infuse aspects of their mythological as well as vernacular language into the dominant language, "one invents a specific, unforeseen, autonomous becoming" (ibid) which sets the stage for revolution and the revival of a new Andean world where the Andean subject is a major agent within the unforeseen future.

Like Quechumara, the categorization of El pez de oro as a minor literature does not imply that Churata should exist under a specific language or genre. Minor literature, like Quechumara, engages in specific practices and conditions rather than existing as specific literary genres of proper languages, "minor no longer designates specific literatures but the revolutionary conditions for every literature within the heart of what is called great (or established) literature" (Kafka 19). When revolutionary conditions present themselves as new avenues for decoloniality, new radical expressions for cultural production present themselves.

What the idea of minor literature helps us to appreciate within Churata's writing are his decolonial practices concerned with emphasizing the loss of cultural and historical agency within Andean lettered production in the developing period of modernity. The deterritorialization of Andean cultural spaces through the imposition of Spanish and writing held larger cultural concerns over mere political ones. Looking forward to the 
next section and a study of "Pachamama," the Andean conception of origin, mythology, culture, life, death, sustenance, and identity spring from the land itself where a loss of territory equates to a complete loss of identity where the Andean subject becomes a nomad within his own land. This conflict of land and cultural production has been a constant tension since the Spanish first arrived and continues to dictate conceptions of Andean reality and the issue of integrating peripheral populations and cultures into the national consciousness.

In Siete ensayos de interpretación de la realidad peruana, José Carlos Mariátegui reminds us that the problem of the indio is one of land and territory yet whose solution can only be a sociopolitical one (23). It is the role of the ayllu within the Andean society which acts as the most foundational structure for an authentic Andean cultural representation. By aligning Churata's writing with minor literature, we can declare that there does exist the possibility of an Andean American Literature and identity by constructing itself within a major language as a means of political and cultural reterritorialization. 


\section{The Hurin Dilemma: Andean Cosmology and the Discovery of America in "Pachamama"}

The period of early twentieth century modernity and the sociopolitical movement of indigenism set forth a cultural framework for the reconfiguration of Andean society and Andean reality where the Andean subject sought to elevate Andean discourse to be level with that of prevailing European systems of knowledge. To accomplish such a task, what was needed was a representation of the Andean reality through an internal Andean perspective. Within this period of increasing self-representation, "the indio, represented by others projections, became the critical component of the new configurations of Andean society and culture" (Coronado 1). This new Andean configuration and representation, led by ideals of forging a new Andean subject, has often been divided into two fields as defined by Mirko Lauer in Andes imaginarios: "indigenismo sociopolítico" and "indigenismo-2" (13). Sociopolitical indigenism is concerned with textual practices engaged with sociopolitical movements and voices of revolution, such as Manuel González Prada and José Carlos Mariátegui. Indigenism-2 encapsulates "la expresión movimiento indigenista" and refers to "todo lo que tuviera que ver con el tema de lo autóctono andino e incluye tanto al agitador radical como al artista amable" (Lauer 13). This inclusion of the artistic voice and the Andean aesthetic within indigenism-2 allowed for a questioning of indigenous identity when defined through an internal Andean perspective. A definition that had historically been defined through the lens of the dominant culture. Within indigenism-2, the Andean could be his own, rather than an othered, subject. 
Lauer's division of indigenism, unified around the communality of the new Andean social configuration, served to distinguish between the tasks carried out in the social or aesthetic landscape. While José Carlos Mariátegui and his political ideals of socialist revolution fit comfortably in the former category, the aesthetic practices of Churata find home in the latter. Even though the distinction between political and aesthetic indigenism allows for different theoretical and critical entrances into Andean studies based on either their political or aesthetic concerns, there remains an unexplored space of Andean representation within this binary — the role of historical fiction and/or metafiction.

This section will investigate the role of historical metafiction within the retablo "Pachamama" of El pez de oro and argue that Gamaliel Churata uses historical metafiction as a decolonial textual theory through dialogic textual practices by forming a meeting place between the European and Andean worldviews. Concerned with both the politics and aesthetics of Andean representation, "Pachamama" offers a unique model of revitalizing indigenous historical memory through an avantgarde and intertextual language which questions the role of colonial historical authority and the verisimilitude of texts regarding first contact.

Inspired in part by the inversions to European historical narratives within Nueva crónica y buen gobierno by Guaman Poma de Ayala and authorial revisions introduced by the mestizo experience in Los comentarios reales by Inca Garcilaso de la Vega, "Pachamama" imposes an Andean cosmological worldview over Christopher Columbus's El diario de a bordo, specifically the diary regarding his first voyage. Similar to Poma and Garcilaso, Churata was intrigued by alterations to a historical record that sought to 
transform the idea of the Andean subject "by offering representations that express indigenous people's own agency as social actors, not objects" (Coronado 168). Yet distinct from Poma and Garcilaso, Churata sought to represent the Andean subject from within his own perspective and led by his own aesthetic language project, Quechumara. In order to place the Andean subject as the principal actor, and author, within his own historical representation, Churata needed to revise historical narrative structures and the role of colonial textual authority.

The idea of history as a permanent and static truth only came about within the Americas through the importation of textuality and documentation as modern technologies. Alterations to historical truths have been engaged by both colonial and mestizo voices, all vying for political and cultural dominance through their claims to historical memory which continue to influence language and traditions. The precolonial Andean lack of alphabetic writing and a bound form of archive reflected a sense of instability and intellectual savagery to European colonial powers where the more tangible and permanent medium of writing was able to implement cultural revisions, or erasures, through the subjective nature of historical documents. The cultural difference blinded European colonizers to the role of differing forms of Andean textuality, namely khipus and corporal archives. While European historical texts were static in their form, their content was highly subjective where various accounts of the same exploration can be greatly distinct from another. The role of Bartolomé de Las Casas within the transcription of Columbus's diary revealed a dependence on fictional narrative structures in order to lend more conflict and resolution to a historical moment. Likewise, a close reading of the 
accounts of cannibalism in the New World reveals a shocking lack of evidence and a predominance of judgments based on a constant othering of indigenous practices.

Despite the form of the book as static, deciphering its content was held to be a privileged position where biblical passages were read aloud by a literate reader and accepted as truth by its illiterate listeners. Thus Spanish existed as a paper language where it was widely orally spoken, but whose textuality was reserved to a privileged minority group. With Andean and European illiterates alike convinced of the mystical elements of writing, despite its unstable nature of subjective content and susceptibility to edits and revisions, the object of the book took on a vital social function as an object of authority and power more than a tool for communication and truth, "the physical book is much more fetish than text and much more an expression of domination than an act of language" (Writing in the Air 29). If writing is lent a fetishized social power as a means of sustaining oral memory, it is allowed a certain domination over orality where it can be argued that only what is written needs to be preserved. Thus, lettered colonial voices were freely given the space to reshape the Andean condition under their own subjective appropriations.

Subjugated under the authority of the written word, Andean cultural autonomy began to suffer and the Andean condition came to be defined by subjective European discourses. Yet this context of textual domination planted the seed of writing as revolution and resistance within Andean and Peruvian literature. Communities began to utilize writing as their greatest tool for liberation. Andean voices like Inca Garcilaso de la Vega and Guaman Poma de Ayala began to insert the mestizo experience into colonial texts regarding Andean history, conquest, domination, and identity. Within the 
framework of writing as resistance, the Andean subject began to gain a new sense of liberation enabled by what had become a heterogeneous literature defined by the intersection of European and Andean discourses.

In Writing in the Air, Antonio Cornejo Polar outlines the product of this period which continues to flourish into contemporary lettered production, "there arises, above all, a new, writing subject, capable of using the written word in Spanish or Quechua, whose very presence, through intermittent and subordinated, substantially alters the order and limits of the lettered space of the Andean nations" (30). Suspending the limits of the lettered space of the Andean nations, the cultural function of Quechua and dramatic performativity return to Andean narratology. From within the conflicts of history, identity, and representation throughout the colonial and direct postcolonial period, narrative authority became disentangled from textual authority where Garcilaso and Poma altered the limits of colonial authority.

Similar to "Homilía del Khori-Challwa," which questioned American identity as being superimposed over Andean reality, "Pachamama" challenges European authority regarding historical representations of first contact with the Americas. In "Pachamama" Churata rewrites the conquest of America where the Andean mythological figures PachaMama bears witness to the arrival of Columbus into the Americas. Narrated through an internal Andean mythological perspective, this retablo presents a dialogic interpretation of arrival where European and Andean discourses fight for authority over colonial conquest and discovery.

Even well before the publication of El pez de oro, Churata wrote extensively on his idea regarding American identity and the place of Andean subjects within it. In 1936 
Churata published a short opinion article titled "La América no existe" where he acknowledges the inherent contradiction in highlighting Columbus discovery as manifest destiny given the fact that Columbus's arrival in the Caribbean was an accident, "no fue América lo que Colón buscaba en las lejanías del Océano; era el país del Gran Khan, o la Lemuria, no América. América surgió como un regalo o un tropiezo dentro de las aguas, y Colón, viejo ya, proseguía convencido de su descubrimiento de las Indias Orientales." The idea of the discovery of America as a siren's song is tantalizing in how Churata seems to imply that it was America that discovered Columbus rather than the other way around. Churata continues this sentiment twenty years later in El pez de oro: "que ni había descubierto a Baneke, ni a la América; pero que Baneke y América a él le descubrieron" (382). Churata rejects the idea of the discovery of a culturally developed locality and asserts that our conception of world history and discovery is backward. It was America that gave Columbus his legacy, not Columbus that lent America its natural and cultural riches to be exploited.

Beyond presenting the discovery of America as an accident, Churata also allows it to be seen as a textualized invention at the cost of the erasure of Andean culture. To return to "Homilía," Churata says, "España menos conquistó América cuanto que la ha inventado...jNo la inventó; la ha borrado! Y el borrador somos nosotros...en quienes ni España vale lo que un cuesco, y el indio menos" (175). Churata challenges the idea of the discovery of a developed civilization and the erasure of their people toward the constitution of a new Spanish Empire. Our Andean narrator uses Andean mythology and infusions of Quechumara toward a more heterogeneous historical record of the moment of first contact between the two opposed worlds. Within "Pachamama" Churata's narrator 
attempts to reconcile the opposing worldviews in an attempt to find common ground between Old and New World discourses. A reconciliation of these distinct worldviews opens up the possibility of a heterogeneous future built on culture just as much as race. Yet they must find some sense of fusion or hybridity to find a sense of historical meaning for both cultures. In his article "Modernity, Identity and Utopia in Latin America," Anibal Quijano makes the point that:

By what mode, if not the aesthetic-mythic, can an account be given of this simultaneity of all historical times in the same time? And what but mythic time can be this time of all times paradoxically, this strange way of revealing the untransferable identity of a history proves to be a kind of rationality, which makes the specificity of that universe intelligible. (150)

Quijano rationalizes that a concentration on the specific mythology and its specific aesthetics, the differences between two opposed cultures and worldviews can be made more visible, and a resolution can be made more viable. The distance between the European and Andean mythologies and aesthetics will be examined in two major strains: concept of past time, and the role of nature. The cultural distance between these concepts favored the colonial dominance of Spain, which allowed Andean history and mythology to be supplanted and erased. Mignolo notes, "the invention of America appropriated the idea of history, colonized time, and space and located Europe as the point of reference of global history" (Darker Side xiv).What Mignolo and Quijano establish, and that Churata agrees with, is that European and Latin American cultures do not experience time, or the relation of the past to the present, in the same way. Thus they must seek a form of narrative reconciliation. By fusing together indigenism with the avantgarde imports of modernity, there exists a textual space for the historical reconfiguration of the Andean subject by enabling their agency more than reigniting a lost past. Frank Salomon notes: 
What Andean writers intended, it seems, was not to preserve Andean thought about the past in an unassimilated cell encysted in the body of Spanish letters, but to re-create it as a totalizing system having the same dimensions as European historical thought, occupying the same space, and yet not conflicting with it. (Salomon 11)

This fissure of differing forms of historical representation, authority, and identity within the same text attempts to revisit colonial texts of conquest in such a way where the space between the literary and the historical, fact and fiction begin to superimpose to a point of hybridity.

The blurred lines between history and fiction are a constant within mythological origins, and also played a role in utopian depictions of an Andean past by voices such as Inca Garcilaso and José Carlos Mariátegui. Both of these figures sought a space for Andean independence through European models of narrative structure and/or thought. Garcilaso, more or less, advocated for a hybrid restructuring of colonial society under a predominance of Western thought. As Jorge Coronado argues in The Andes Imagined, while Mariátegui understood his own reliance on European thought, he rejected the need for a cultural hybridity as it was the figure of the indio, rather that Andean culture, which was useful to incite socialist revolution and national reform. Churata stands out from both of these figures by using the idea of cultural hybridity to create a dialogic text that sheds historical truth in favor of mythological origins. Shedding a need for truth in favor of symbolism, we return to the symbolic role of mythological figures within the Andean mythos.

While never referred to directly, the title of the retablo as "Pachamama" invokes a consideration of the important role of nature and the three distinct worlds related to the Andean cosmovision. The Quechua word "Pachamama" itself refers to the role of Mother 
Nature as the provider of life and death. Yet it would be inaccurate to describe the Andean conception of Pachamama as "nature" in itself. For European audiences, nature is a constant presence of an ungodly world, the natural world exists outside of European culture. Christians may be molded from mud, but were given life by the hands of God. As Churata will go on to evidence, within the Andean mythology Pachamama is what lends life and no life can exist outside her. Walter Mignolo summarizes this distinction well in

\section{The Darker Side of Western Modernity:}

For Aymaras and Quechuas, more-than-human-phenomena (as well as human beings) were conceived as Pachamama; and, in this conception, there was not, and there is not today, a distinction between "nature" and "culture." Aymaras and Quechuas saw themselves in it, not separated from it. As such, culture was nature and nature was (and is) culture. Thus the initial moment of the colonial revolution was to implant the Western concept of nature and to rule out the Aymara and Quechua concept of Pachamama. This was basically how colonialism was introduced into the domain of knowledge and subjectivity. (11)

As Churata will go on to execute throughout the entire retablo, a recuperation of mythological figures and beliefs can equate to a recuperation of historical memory and agency. Once Andean mythology, a symbol for culture and nature, can be appropriated to fit more Western definitions of the proper role of nature within a mythology, the entire mythos disintegrates and colonial powers can insert their own systems of knowledge.

Besides the giver and taker of life, the prefix "pacha-" holds a meaning fixed to three distinct Andean worldviews. First, kaypacha refers to the world as we experience it; the surface reality of earth and water. Second, ukhupacha is the Andean underworld where the spirits and bones of Las Chullpas remain. Third, hananpacha is the celestial sky of day and night. There exists natural conflict between these worlds, known as the hurin dichonomy, where kaypacha and hananpacha battle for presence in the 
experienced world. In this way, it can be argued that kaypacha exists as a conflict and tension between the world from below and the world from above. Much like the KhoriChallwa who exists as the product of tension between the new and old world, the existence of our world is situated as a symbolic mythological tension. The recasting of the discovery of America is, thus, presented as a discovery of the land of the celestial universe, hananpacha:

Khori-Puma se arrancó los ojos de las cuencas, que hoy tiene ardidas con mi fuego en su matinal sepulcro, pues así me estaban mejor, engarzados en Mirya. La nubecilla boyeaba en las atmósferas. Libre de nubes de jabón, el Sol, su joyante cáscara de nuez achicharraba en el abismo, doraba el plumón de las aves, granizaba abejas de miel. Y de esta guisa, hasta el mestizo patiecito cargado de begonias, en mansas oleadas llegaba el resuello del Universo. (388)

The Andean mythological worldview was clearly not overly focused with attempts at verisimilar representation of Andean origins. And returning to Quijano's quote, this juxtaposition of a European discovery myth in a very Andean aesthetic is a confounding narrative, yet one where the Andean mythology is made all the more tangible through a western narrative structure.

Distinguishing himself from other indigenistas who often depict the Andean past as an idealized utopia, Churata depicts a mythological and symbolic past. Like Quechumara and modernity, Churata was intrigued by the possibility of future cultural engenderment rather than regressive utopias, "utopia is, after all, a project for the reconstitution of the historical meaning of society" (Quijano 153). For authors and historians engaged with the revival of the Andean past as a mythical or idealized one, this "reconstitution of the historical meaning of society" meant depicting Andean history in such a way to be favorable to colonization and conversion, or toward ideologies meant to 
inspire future revolution and cultural consciousness. To this end, the social goals of literary and historical production have never been seen as entirely distinct, "literature and history were considered branches of the same tree of learning, a tree which sought to 'interpret experience', for the purpose of guiding and elevating man” (Nye 123). Yet the reconstitution of the Andean past as an idealized utopia was never a goal of Churata, the ideal of "guiding and elevating man" for Churata instead meant guiding the new Andean subject towards the restitution of his own cultural agency by tracing the discovery of origins as rooted in myth. As Khori-Puma rides the waves of air on a boat of clouds, the formation of the universe and the place of the Andean subject within it find themselves rooted in myth over truth.

The role of discovery and origin myth holds a predominant position within "Pachamama" where Columbus presents his arrival in the New World as its origin. The origin of this New World for Columbus was one rooted in Christian religious myth where the arrival of the Europeans was depicted as a sort of divine interference. Churata utilizes intertextual and dialogic intervention to challenge Columbus's mythical orientation, “ $¿ Y$ si de allí no, Cristoforo, de dónde?" (Churata 376). This opening line of "Pachamama" places itself in conversation with the diary of Columbus which argued that the indios believed that the mariners had fallen from the sky and that the conquistadors were, in fact, gods. Shifting away from the Andean mythological worldview toward the European one, Churata questions whether Western civilization appreciates the role of myth within their own origin stories:

Que genial el marinero...Los Kanibas le habían dicho que vino del cielo, y era lo sensato, silogístico, y único admisible, ya que no podía del regüeldo de la ballena de Jonas a causa de que entonces era muerta; y para que de otra ballena fuera, 
fuera menester milagro, milagro a quien se oponían las poco esclarecidas mancebías de que parecen resultado algunos de los eslabones de su cadena, y que no poco le abonaban famas de pudendo en el cielo, aunque en el otro, no en aquel a que los Kanibas habían hecho referencia, según cree que creen... (375)

The biblical references, and specifically to the tale of Jonah fill a few important roles within the larger context of colonization and origin myth. Jonah is a biblical figure who was caught in a torment at sea similar to the storms that nearly derailed Columbus' voyage, and is sacrificed by his crew and thrown overboard where he is consumed by a whale before being regurgitated three days later. Churata references Jonah as being devoured and later resurrected by a mythological fish. Much like Jonah, the Andean world was consumed by a foreign mythos to later be resurrected, lending them the space for a new concept of origin. Moreover, Khori-Challwa was consumed by his father, Khori-Puma, before being regurgitated and re-emerging as a symbol for a new Andean future. Churata attempted to create a shared space of mythological origins where both cultures could see their shared structural origins based in myth, which both shared the nucleus of a virgin birth, "toda virginidad es maternidad" (389). The role of maternity and birth serves as an origin for both cultures where life comes from nothing other than the elements of the Earth and divine intervention.

While Churata sees the land as a unifying force which contains traces of origin, he holds a strong distrust of myth as truth, "aunque el hombre no comprende hoy, tendrá que enterarse que aquello que principio tuvo no existe" (El pez de oro 407). This closing line of "Pachamama" reiterates his appeal toward rejecting cultural conditions as being inherent to our bodies and false origins where the individual subject creates his own conditions, "fuera de ti nada hay" (ibid). The division between the opposed worldviews 
that Churata seeks to highlight is one where the Andean origin myth understands the historical role of myth as narrative while the European worldview is more prone to interpret biblical myths as historical truths, and our social conditions as preordained.

The conception of Andean and European origin myths as stemming from the same narrative chain, Churata references toward a place of commonality between the two discourses. Yet what Columbus' diary, and Churata's rebuttal, implies is that Columbus attempted to portray the historical origins of the "Kanibas" 26 as beginning with his arrival and that they lacked any notable prior history. By lending them an identity and asserting that the indios believed that their gods would descend from the skies, Columbus asserts himself, not only as the discoverer of their land, but as the mythical figure meant to "guide and elevate" the backward indios towards enlightenment. By linking an origin myth to his discovery, Columbus places himself between history and fiction and assumes the role as a figure of unquestioned historical authority.

Given the historical record of Columbus, we know that his authority was questioned and was virtually ignored well into the development of the Americas, and for good reason. No colonial text conveys the subjective nature of history and the impossibility of knowing its truth more than the diaries of Christopher Columbus.

Columbus's diaries represent the first texts dedicated to the discovery of the New World where any representation could present itself as truth without any conflicting accounts. Margarita Zamora notes in "Todas las palabras formales del almirante": "en el texto colombino lo imaginario se transforma en realidad histórica, aunque una historia

\footnotetext{
${ }^{26}$ A sarcastic use of "los Kanibas" which seems to be a hybrid naming that fuses Columbus's misconception of arriving at el Gran Khan (Asia), as well as his eventual characterizing of these indigenous inhabitants as cannibals.
} 
empapada de los lenguajes del mito, la leyenda, y la maravilla que la habían anunciado" (25). This lack of textual antecedent allowed Columbus to depict the natives unfettered by any previous historical record, thus unchaining his imagination from any sense of reality where historical meaning and context "are as much invented as found and the forms of which have more in common with their literature than they have with those in the sciences" (White 82, original emphasis). Columbus's flexibility to insert fiction into the historical record comes through within the mythological origins he assigns to his arrival and discovery of the New World.

Moreover, the editorial intervention of Bartolomé de Las Casas cannot be overlooked when conceiving of the historical authority of Columbus's account. Given that the original document was transcribed by Las Casas, the authenticity and historical truth of the text have justifiably been thrown into doubt even though it had been held as, what Zamora calls, "a historical source of unparalleled authority" ("Historicity and Literariness" 342). More than altering events to align more closely with his personal ideology, Las Casas certainly edited the historical record to fit more appropriately into a narrative structure that allows for tension, conflict, resolution, and other discursive elements of fiction. Zamora again:

Las Casas no solo resume parafrasea el enunciado colombino, sino que se inserta en el texto como nuevo sujeto de la escritura, imponiendo una retórica editorial que no podía haber existido en el texto original. Altera su contenido mediante la representación selectiva de las palabras del Almirante, pero de manera aún más fundamental esta nueva retórica editorial también altera el tipo de lectura del texto que podemos hacer, es decir, modifica el proceso de interpretación y por ende el significado que le atribuimos al texto. ("Todas las palabras" 29)

Taking these textual alterations and reading them through Hayden White's idea of "emplotment," which addresses the "encodation of the facts contained within a chronicle" 
(83), Las Casas' textual intervention reveals the inherent links between the historical and the literary, including the construction of an intentional plot structure to what should be a chronological witness testimony. The questioning of historical authority through Las Casas' reliance on fictional plot structures confuses classifications of the historical and the literary to a point where they overlap and truth becomes a secondary concern to narrative plot structure, conflict, and resolution.

If the distinction between the historical and the literary is narrow and both genres are porous, then it stands to reason that there exists a textual space where history and fiction overlap, influence, and blend into one another. Linda Hutcheon notes: "fiction and history are narratives distinguished by their frames, frames which historiographic metafiction both asserts and crosses" (59). As Hutcheon goes on to argue, historical metafiction opens itself up to intertextual dialogues between history and fiction, and their shared goals of constructing a closed narrative of representation. This historical metafictional dialogue allows for a reconstitution of what is meant by historical knowledge, historical meaning, and the formation of cultural identity and tradition.

The role of intertextuality is dominant within "Pachamama" where Churata constructs the Andean chronicle of discovery around quotations and moments taken from Columbus' diary. As seen from the first sentence, Churata goes on to quote the diary multiple times throughout his metafictional retablo "te brindo mis 'fermosas' verduras y mis señoras no menos 'fermosas'; y si me resultas bueno tal vez huelas lo que buscas" (382). More than a fictionalized historical narration that utilizes quotations from the original diary, Churata subordinates the authority of Columbus by presenting the past as susceptible to change and cyclical in nature. 
One of the great divisions between European and Andean narrative structures is the role of chronology and cause and effect. For European biblical thought, every action or event holds significant meaning where the totality of our actions ultimately culminate in our judgment before the Christian God. History within the Andean worldview was cyclical rather than linear where time is repetitive and permanent; the role of the cosmos and the worship of planetary cycles attest to the Andean idea of history as cyclical rather than lineal. While European textual discourse allows for one fixed outcome, the Andean dramatic discourse is distinct. Antonio Cornejo Polar notes in Writing in the Air: "it does not so much evoke the story as renew it symbolically, and upon "repeating" it in an everchanging present, it neither prefigures nor ordains an outcome" (33). From this narrative distance, the arrival of the Spanish into the New World presented a narrative conflict that went against the Andean worldview. Rolena Adorno explains in From Oral to Written Expression, "the conquest of Tawantinsuyu by invaders from abroad does not lend itself to a cyclical, archetypal interpretation of history" (113). This inversion to Andean narratology opened up a creative space where the two structures could be used on the same page.

Churata was able to implement traces of the circular Andean narrative into the diary of Columbus through using intertextual and extratextual reference regarding the legacy of Columbus, a legacy which was largely inexistent up until the nineteenth century when reinvigorated by North American nationalists. Churata introduces this legacy as the Andean narrator depicts Columbus' arrival in the New World:

Si las aguas de 'la mar océana' están en la tierra, en la tierra habitan, y la tierra en el cielo, decirle que vio de éste revela sólo que los antropófagos de Kanidia eran 
cuando menos más reflexivos y observadores que el Almirante. Y este sublime iluso nos descubrió....No puede nadie descubrir un mundo descubierto. (376)

The reference to "la mar océana" and Columbus' title as "Almirante" evoke a conversation with texts regarding the eventual legacy of Columbus where he was regarded as "Almirante del mar océana" by the Catholic Church after his initial voyages. Through utilizing future texts and the eventual legacy of Columbus, Churata allows a history that circulates between the past and the present, rather than existing in a fixed moment in the past that moves toward the present.

Through intertextuality, Churata not only allows a space for an Andean revision to European texts but also places himself in intertextual conversation with texts that emerged after Columbus's voyage. That is to say that Andean history needs to be presented as unknowable and fictionalized in order for any future cultural transformation to take place within the heterogeneous society. Colonial history must be put into doubt for the new Andean subject to have any sense of agency over their future, something that Churata accomplishes by re-writing and de-centering colonial historical authority. Churata makes it clear that Columbus' historical record is fiction, and his legacy as well through a period of direct address to Columbus ghost, "no te perdonaremos, y es que callaras cuando te bautizaron 'descubridor de indias'. Tú no has descubierto, Colon...sabes que el Imperio de Kanidia no es el Imperio del Khan...Este Imperio se interpuso entre tus sueños y los del Gran Khan" (403-404). Churata takes his de-centering of authority to a new level of discourse by going further than direct address to a metahistorical approach of rewriting the historical account under Churata's own historical interpretation and narration. 
In Seymour Menton's treatment on the new historical novel, the act of re-writing and/or inserting new dialogue into a historical record may be read as a parody of European chronicles. Churata engages in a series of these metafictional textual mutations by re-writing portions of the diary under his own interventions of narration and new dialogue:

Martín Alonso, "pidiéndole albricias", gritara al Almirante, que "vido" tierra. Y tierra no era: ERA EL PEZ DE ORO.

Y fueron los descubridores...

Alzaran un junquillo de las aguas, le miraran, una y otra vez, no poco estupefactos, si por enchapes, y rubís, y esmeraldas, coligieran que la insignia era del Warayok de Kanidia, adelantando regio de su estupenda presencia. Y nos han descubierto.

"Allí están ellos" pensaba, dentro el Almirante, otro, otro, perspicuo y nada bobo: allí están.

Y, luego:

"Mira, Cristóforo: todo esto a cuenta de que agarraron los badajos, y presto oiremos campanas" (378)

The historical metafictional practice of re-writing a historical text is a long-sustained tradition that can be used to disrupt a homogeneous style of language. As Bakhtin notes, "images of language are inseparable from images of various world views and from the living beings who are their agents" (49). Through introducing a heterogeneous style of language and discourse, Churata is successful in disrupting any center of literary language or historical authority which allows the heterogeneous language to construct a cosmological worldview that is "multi-generic, multi-styled, mercilessly critical, soberly mocking, reflecting in all its fullness the heteroglossia and multiple voices of a given culture, people, and epoch" (Bakhtin 60). The presence of heteroglossic discourse, one where opposing worldviews and/or languages share a space, presents an evolving heterogeneous and dialogic worldview where no one discourse dominates the other. In 
this way, the cultural autonomy of Andean representation can begin to take shape.

Bakhtin rationalizes how heteroglossic discourse allows for the reconstitution of selfrepresentation:

They [heteroglossic forms] liberated the object from the power of language in which it had become entangled as if in a net; they destroyed the homogenizing power of myth over language; they freed consciousness from the power of the direct word, destroyed the thick walls that had imprisoned consciousness within its own discourse, within its own language. A distance arose between language and reality that was to prove an indispensable condition for authentically realistic forms of discourse. (60)

Bakhtin allows for a new discourse as the product of a dialogic conflict that comes together as a unified whole. This heterogeneous discourse does not differ from the idea of a cosmological worldview that Churata envisions as necessary for the emergence of the new Andean subject.

The role of origin, myth, and language in "Pachamama" attest toward the decolonial goal of creating a heteroglossic historical text that speaks towards European and Andean sensibilities through a meshing of their opposing worldviews. At the center of this metafictional historical text lies an appeal toward the cosmological ideal that seems to drive Churata from his childhood where the conflict between indigenous and occidental worldviews was a constant. In order to reflect his own "multi-generic, multistyled" voice, Churata promotes the notion of cosmological unity to reconcile the distances of language, truth, and myth within historical records, "la Pachamama que esté y no esté en todos los sistemas del Universo...ignoramos lo que de ella piensan los habitantes de otros planetas" (383).

For Churata, the mythological figure of Pachamama acts as the foundation for the reconciliation of distinct historical worldviews through her depiction as time, space, and 
mother nature who engenders life, "por ser madre en tiempo y espacio, que espacio es, y solo ella secreta tiempo...fuera de ella nada puede ser ni estar" (384). Presenting Pachamama as the land itself and inferring a sense of connectivity between the land and the stars, "la estrella, siempre la estrella; lo que nos acredita que somos estrellas, vivimos en estrella, y nos esperan en la estrella...saben que todo está en el cielo; que el cielo es la tierra" (387), Churata refers to our shared physical existence of time and space tied to the land under the same cosmos. This focus on lending a universal cosmology to colonial historical accounts stands out as one interested in depicting the division of modernity as more complicated than a pre- and post-Columbian distinction.

What texts like Columbus' attempted to record was the discovery of a world without the slightest trace of history, rationality or democracy. This Eurocentric focus empties the indigenous cultures of their distinct non-European modernities and robs them of their historical memory. While not interested in resuscitating the forgotten past, what Churata does offer is a historical metatext which acknowledges non-European contributions to modernity, such as the emergence of new heterogenetic structures of governance and representation. As Walter Mignolo has stated in "Geopolitics of Knowledge and the Colonial Difference," the creation of knowledge and social critiques that emerge within a colonial system can be directly attributed as "a necessary move of decolonization" (251). A re-writing of colonial historical accounts through a metafictional lens towards modern means of elevating the Andean subject and inciting the instability of the historical genre are fitting examples of modernity springing from the colonial condition. 
What this section has argued is that the coexistence of colonial and Andean interpretations of the past through a metafictional and decolonial process enabled the emergence of a heterogeneous historical text; one where no single historical interpretation, or culture, is given authority over the idea of the past as an objective fixed moment. This heterogeneous history is one rooted in conflict of ambiguity where the Andean subject assumes agency over their representation, but through European forms. Conflicts of authority, language, and historical truth can be seen throughout "Pachamama" where the Andean subject places himself in conversation with the chronicles of first contact and the enduring legacy of the discovery of the New World. Churata inserts his narrator into the diary of Columbus as a means to de-center textual authority and reveal how Columbus's text has often been subject to extratextual edits and alterations in an attempt to mingle classifications of the historic and the literary. This textual meeting place of history and fiction, past and present, truth and myth, and the European against the Andean lend a cosmological worldview where the reconstitution of the mythical Andean world takes place within European narrative structures. By capturing their own voice, language and narrative while dismantling the need to fit within the literary or historic genre, this dialogic retablo of El pez de oro creates a space for the growth of the new Andean subject and the new Andean future. 


\section{Conclusion}

What this thesis has attempted to convey is that the invention of America presents multiple cultural conflicts to dominated American subjects where their origin, history, culture, race, and representation are imposed identities that strip the native subject from any connection to the land or language from which their culture was constructed. In relation to the Andean American subject, the Andean has lost connection to their mythological origins and indigenous languages that sustained their traditions to the Andean altiplano for centuries. In hand with the displacement of Andean subjects from their culture are the consequences of modernity which continue to transform the altiplano landscape and Andean culture at a much more rapid pace than colonialism could ever aspire. Decoupled from his origins as a result of colonialism and in the face of industrialized modernity, the colonial Andean subject is then sent out as a nomad within his own world in search of traces of his lost culture.

Unlike the North American identity where the American subject rejoices in his disconnect to place and the possibilities that the New World presents, the Latin American identity is one that endlessly attempts to revive their connection to land and culture. Yet as Churata argues throughout El pez de oro, a blossoming of these cultural will not come about by harvesting the lost past. Rather than a historical project engaged with reviving pre-American reality, Churata sought this excavation through tracing the roots of cultural language and allowing them to infuse themselves into colonial reality.

For Churata, the American identity does not yet exist, but it remains a possibility going into the future where the Andean subject can find new strategies of infusing Andean culture into the national language, consciousness, and literature. Born in the age 
of modernity where Puno and the altiplano region were rapidly altered by industrialization and new modes of communication, Churata was intrigued by the possibilities of the oncoming globalized future where Andean culture could vanish if not invested more with future projects over historical revivals.

Engaged with the possibilities of future identity projects enabled by future technologies, Churata presents himself as a cultural critic and theorist whose interpretations and theories will continue to become more relevant and applicable in the current age of social media, internet communication, and ever-emerging new technologies that are forcing new considerations of national and cultural identity. Just as modernity rapidly altered Andean reality and their modes of communication, Latin American identity is currently undergoing a comparable rapid evolution of communication enabled by social media and new technologies that can enable new modes of minority groups to infuse their colonial identity toward the constitution of a truly heterogeneous identity. It is worth repeating that this heterogeneous identity is not a racial one, we are not discussing the possibility of a mestizo project. Rather, Churata presents the possibility of a new, and true, American identity as the product of an aesthetic project where language constitutes the most foundational component of this future identity.

More than an Andean intellectual and writer who foresaw the impending role that globalization would play within the reconsideration of national identity, Churata is a figure that I believe will come more into focus with the oncoming publication of his many unpublished manuscripts. Led by Riccardo Badini and Helena Usandizaga, other texts by Churata are set to be released in the coming years where the constitution of 
Churatian Studies as an academic strain will gain more momentum where his fiction, non-fiction, metafiction, poetry, and sociopolitical writings can constitute a wide body of work that can help situate Gamaliel Churata alongside many of his peers and to resurrect his legacy as having left an impact on critical engagements with, not only colonial or Andean identity, but the invention of American identity in itself. 


\section{References}

Adorno, Rolena, editor. From Oral to Written Expression: Native Andean Chronicles of the Early Colonial Period. Syracuse University, 1982.

---. "Reconsidering Colonial Discourse for Sixteenth- and Seventeenth-Century Spanish America." Latin American Studies Review, vol. 28, no. 3, 1993, pp. 135-145.

Aguiluz Ibargüen, Maya, editor. Encrucijadas estético-Politicas en el espacio andino. UNAM, 2009.

Albornoz, Cristóbal de. "Instrucción para descubrir todas las huascas del Pirú y sus camayos y haciendas." Journal de la Societé des Américaniestes, vol. 56, 1967, pp. 17-39.

Arguedas, José María. Indios, mestizos y señores. Horizonte, 1989.

Astvalddson, Astvaldur. "Myth, Cultural Memory, and Resistance in Latin American Narratives." Bulletin of Hispanic Studies, vol. 88, no. 6, 2011, pp. 617-633.

Ayala, José Luis. "El pez de oro: Piedra de toque para un proceso de descolonización de la Literatura. Blogspot. Feb. 2012

http://elcholoayala.blogspot.com/2012/02/el-pez-de-oro-piedra-de-toque-paraun.html. Accessed 10 December 2016.

Badini, Riccardo. "La ósmosis de Gamaliel Churata." Memorias de JALLA Tucumán, vol. 1, 1997, pp. 344-351.

---. "Los inéditos de Gamaliel Churata." Encrucijadas Estético-Políticas en el espacio andino. Edited by Maya Aguiluz Ibargüen, UNAM, 2015, pp. 207-214.

Bakhtin, M.M. The Dialogic Imagination. Texas UP, 2000.

Bosshard, Marco. Churata y la vanguardia andina. Latinoamericana Editores, 2014.

Bourricaud, François. Cambios en Puno. Instituto Indigenista Indoamericana, 1967.

Churata, Gamaliel. El pez de oro. Edited by Helena Usandizaga, Cátedra, 2012.

---. "La América no existe." La calle. 12 October 1936, La Paz.

Cornejo Polar, Antonio. Writing in the Air. Translated by Linda J. Jentsch, Duke UP, 2013.

---. La formación de la tradición literaria en el Perú. CEP\& Centro de estudios y publicaciones, 1989.

Coronado, Jorge. The Andes Imagined. Pittsburgh UP, 2009.

Coronil, Fernando. "Elephants in the Americas? Latin American Postcolonial Studies and Global Decolonization." Coloniality at Large. Edited by Mabel Moraña, Enrique Dussel and Carlos A. Jáuregui, Duke UP, 2008, pp. 396-416.

Cortez, Enrique. 'El Inca Garcilaso, 'Clásico de América,' en las obras de José de la Riva-Agüero y Marcelino Menéndez Pelayo.” Revista Crítica Literaria Latinoamericana, vol. XLI, no. 82, 2015, pp.73-94.

Cummins, Tom. "Representation in the Sixteenth Century and the Colonial Image of the Inca." Writing Without Words. Edited by Elizabeth Hill Boone and Walter Mignolo, Duke UP, 1994, pp. 188-219.

Deleuze, Gilles, and Félix Guattari. Kafka: Toward a Minor Literature. Minnesota UP, 1986.

---. A Thousand Plateaus: Capitalism and Schizophrenia. Minnesota UP, 1987. 
Díez de Molina, Fernando. "Gamaliel Churata y El pez de oro.” Antología y valoración. Ediciones Instituto Puñeno de Cultura, 1971, pp. 392-399.

Dussel, Enrique. "Philosophy of Liberation, the Postmodern Debate, and Latin American Studies." Coloniality at Large. Edited by Mabel Moraña, Enrique Dussel and Carlos A. Jáuregui, Duke UP, 2008, pp. 335-349.

Fernandez Moreno, César. América Latina en su literatura. Siglo XXI, 1972.

Fraser, Robert. Book History through Postcolonial Eyes. Routledge, 2008.

Gonzalez Fernandez, Guissela. El dolor americano: Literatura y periodismo en Gamaliel Churata. Fondo Editorial del Pedagógico San Marcos, 2009.

Huamán, Miguel Ángel. "En defensa del indigenismo.” Letras, vol. 80, no. 115, 2009, pp. 11-25.

Hutcheon, Linda. "The Pastime of Past Time: Fiction, History, Historiographic Metafiction.” Postmodern Genres. Edited by Marjorie Perloff, Oklahoma UP, 1989, pp. 54-74.

Hulme, Peter. "Postcolonial Theory and the Representation of Culture in the Americas." Coloniality at Large. Edited by Mabel Moraña, Enrique Dussel and Carlos A. Jáuregui, Duke UP, 2008, pp. 388-395.

Lauer, Mirko. Andes imaginarios; Discursos del indigenismo-2. Centro de Estudios Rurales Andinos Bartolomé de Las Casas, 1997.

Maldonado-Torres, Nelson. "Thinking through the Decolonial Turn: Post-continental Interventions in Theory, Philosophy, and Critique - An Introduction.”

Transmodernity: Journal of Peripheral Cultural Production of the Luso-Hispanic World, vol.1, 2011, pp. 1-15.

Mamani Macedo, Mauro. Quechumara: Proyecto estético-ideológico de Gamaliel Churata. Fondo Editorial UCH, 2012.

Mariátegui, José Carlos. Siete ensayos de interpretación de la realidad peruana. Editorial Universitaria, 1955.

Menton, Seymour. Latin America's New Historical Novel. Texas UP, 1993.

Mignolo, Walter. "Geopolitics of Sensing and Knowing; on (De)Coloniality, Border Thinking and Epistemic Disobedience.” Postcolonial Studies, vol. 14, no. 3, 2011, pp. 273-283.

---. The Darker Side of Western Modernity: Global Futures, Decolonial Options. Duke UP, 2011.

---. "Geopolitics of Knowledge and the Colonial Difference." Coloniality at Large. Edited by Mabel Moraña, Enrique Dussel and Carlos A. Jáuregui, Duke UP, 2008, pp. 225-258.

Monasterios, Elizabeth. La vanguardia plebeya del Titikaka. Plural editores, 2015.

Moraña, Mabel. Churata postcolonial. Latinoamericana editores, 2015.

---, et al., editors. Coloniality at Large: Latin America and the Postcolonial debate. Duke UP, 2008.

Nye, Russel B. "History and Literature: Branches of the Same Tree." Essays on History and Literature. Edited by Daniel Aaron, Ohio UP, 1966, pp. 123-62.

Oquendo de Amat, Carlos. 5 metros de poemas. Editorial Decantar, 1969. 
Peralta, Amaratt. Gamaliel Churata: Envisioning the Circulation of Andean Epistemologies in the Age of Globalization, University of Pittsburgh, 4 Nov 2016, Cathedral of Learning. Special Guest Lecture.

Peralta Vásquez, Ántero. "Ha muerto Gamaliel Churata." Correo, 20 de noviembre de 1969, Arequipa.

Quijano, Aníbal. "Modernity, Identity, and Utopia in Latin America." Boundary 2, vol. 20, no. 3, Autumn 1993, pp. 140-155.

Salomon, Frank. "Chronicles of the Impossible: Notes on Three Peruvian Indigenous Historians." From Oral to Written Expression: Native Andean Chronicles of the Early Colonial Period. Edited by Rolena Adorno, Syracuse University, 1982, pp. 9-33.

Schmitt, Carl. The Nomos of the Earth in the International Law of the Jus Publicum Europaeum. Telos, 2003.

Tamayo Herrera, José. Historia social e indigenismo en el Altiplano. Ediciones Treintaitrés, 1987.

Valcárcel, Luis E. Tempestad en los Andes. Universo, 1972.

Varallanos, José. "Churata, su obra, y el indigenismo o peruanismo profundo." Gamaliel Churata: Antología y valoración. Instituto Puneño de Cultura, 1971, pp. 400-414.

Velásquez Garambel, José Luis. Indigenismo, orkopata y Gamaliel Churata. Scribd Database, https://www.scribd.com/doc/57398163/Orkopata-Indigenismo-yGamaliel-Churata

Vich, Cynthia. Indigenismo de vanguardia en el Perú: Un estudio sobre el Boletín Titikaka. Fondo editorial de la Pontificia Universidad Católica del Perú, 2000.

Vilchis Cedillo, Jorge. "El andar de Churata en Bolivia." Encrucijadas estético-políticas en el espacio andino. Edited by Maya Aguiluz Ibarguen, UNAM, 2009, pp. 237252.

---. Arturo Pablo Peralta Miranda: Travesía de un itinerante. América Nuestra, 2008.

Unruh, Vicky. The Latin American Vanguards. California UP, 1994.

Usandizaga, Helena. "Introducción." El pez de oro. Edited by Helena Usandizaga, Cátedra, 2012, pp. 12-121.

White, Hayden. Tropics of Discourse: Essays in Cultural Criticism. John Hopkins UP, 1978.

Zamora, Margarita. "Todas las palabras formales del Almirante: Las Casas y el diario de Colón." Hispanic Review, vol. 57, no. 1, winter 1989, pp. 25-41.

---. "Historicity and Literariness: Problems in the Literary Criticism of Spanish American Colonial Texts." MLN, vol. 102, no. 2, Hispanic Issue, Mar. 1987, pp. 334-346. 